\title{
The Upper Jurassic Garedu Red Bed Formation of the northern Tabas Block: elucidating Late Cimmerian tectonics in east-Central Iran
}

\author{
Markus Wilmsen $^{1} \cdot$ Franz Theodor Fürsich $^{2} \cdot$ Kazem Seyed-Emami ${ }^{3} \cdot$ Mahmoud Reza Majidifard $^{4}$
}

Received: 13 October 2020 / Accepted: 11 January 2021 / Published online: 17 February 2021

(c) The Author(s) 2021

\begin{abstract}
The Garedu Red Bed Formation (GRBF) of the northern Tabas Block (Central-East Iranian Microcontinent, CEIM) is a lithologically variable, up to 500-m-thick, predominantly continental unit. It rests gradually or unconformably on marine limestones of the Esfandiar Subgroup (Callovian-Oxfordian) and is assigned to the Kimmeridgian-Tithonian. In the lower part, it consists of pebble- to boulder-sized conglomerates/breccias composed of limestone clasts intercalated with calcareous sandstones, litho-/bioclastic rudstones and lacustrine carbonates. Up-section, sharp-based pebbly sandstones and red silt-/finegrained sandstones of braided river origin predominate. Palaeocurrent data suggest a principal sediment transport from west to east and a lateral interfingering of the GRBF with marine greenish marls of the Korond Formation at the eastern margin of the Tabas Block. Westwards, the GRBF grades into the playa deposits of the Magu Gypsum Formation. Red colours and common calcretes suggest arid to semi-arid climatic conditions. The onset of Garedu Red Bed deposition indicates a major geodynamic change with the onset of compressive tectonics of the Late Cimmerian Tectonic Event (LCTE), being strongest at the eastern margin of the northern Tabas Block. When traced southwards, the same tectonic event is expressed by extension, indicating a shift in tectonic style along the boundary fault between the Tabas and Lut blocks. The complex Upper Jurassic facies distribution as well as the spatio-temporal changes in tectonic regime along the block-bounding faults are explained by the onset of counterclockwise vertical-axis rotation of the CEIM in the Kimmeridgian. The block boundaries accommodated the rotation by right-lateral strike slip, transpressional in today's northern and transtensional in today's southern segments of the block-bounding faults. Rotation occurred within bracketing transcurrent faults and continued into the Early Cretaceous, finally resulting in the opening of narrow oceanic basins encircling the CEIM. Palaeogeographically, the GRBF is part of a suite of red bed formations not only present on the CEIM, but also along the Sanandaj-Sirjan Zone (NW Iran), in northeastern Iran and beyond, indicating inter-regional tectonic instability, uplift and erosion under (semi-)arid climatic conditions across the Jurassic-Cretaceous boundary. Thus, even if our geodynamic model successfully explains Late Jurassic tectonic rotations, fault motions and facies distribution for the CEIM, the basic cause of the LCTE still remains enigmatic.
\end{abstract}

Keywords Facies analysis $\cdot$ Depositional environments $\cdot$ Palaeogeography $\cdot$ Synsedimentary tectonics $\cdot$ Geodynamic model

Markus Wilmsen

markus.wilmsen@senckenberg.de

Franz Theodor Fürsich

franz.fuersich@fau.de

Kazem Seyed-Emami

kemami@ut.ac.ir

Mahmoud Reza Majidifard

m_majidifard@yahoo.com
2 GeoZentrum Nordbayern, Fachgruppe Paläoumwelt, Friedrich-Alexander-Universität Erlangen-Nürnberg, Loewenichstr. 28, 91054 Erlangen, Germany

3 School of Mining Engineering, University College of Engineering, University of Tehran, P.O. Box 11365-4563, Tehran, Iran

4 Research Institute for Earth Sciences, Geological Survey of Iran, Box 13185-1494, Tehran, Iran

1 Museum für Mineralogie und Geologie, Senckenberg

Naturhistorische Sammlungen Dresden, Sektion

Paläozoologie, Königsbrücker Landstr. 159, 01109 Dresden,

Germany 
Fig. 1 Structural and lithostratigraphic framework plus locality details. a Main structural units and sutures of Iran (modified after Wilmsen et al. 2009b); the small rectangle shows the study area in the northern Tabas Block. b Close-up of the study area showing the position of the studied sites: 1, type section of the Garedu Red Bed Formation (GRBF); 2, section north of Honu; 3, Ozbak-Kuh; 4, Kuh-e-Talkhori and Kuh-eMehregani; 5, type section of the Nar Conglomerate Member of the Magu Gypsum Formation; 6, Kuh-e-Birg; 7, Esfak conglomerates (asterisk coloured in blue because the section does not expose the rocks of the Garedu Subgroup but reflects the marine record of the onset of the Late Cimmerian tectonics). The principal position of the lithostratigraphic transect of Fig. 1c is indicated. c Simplified lithostratigraphy of the upper Middle and Upper Jurassic (Esfandiar and Garedu subgroups)on the northern Tabas Block (modified after Wilmsen et al. 2003, 2009a); M. Jur. Middle Jurassic; LCTE Late Cimmerian Tectonic Event
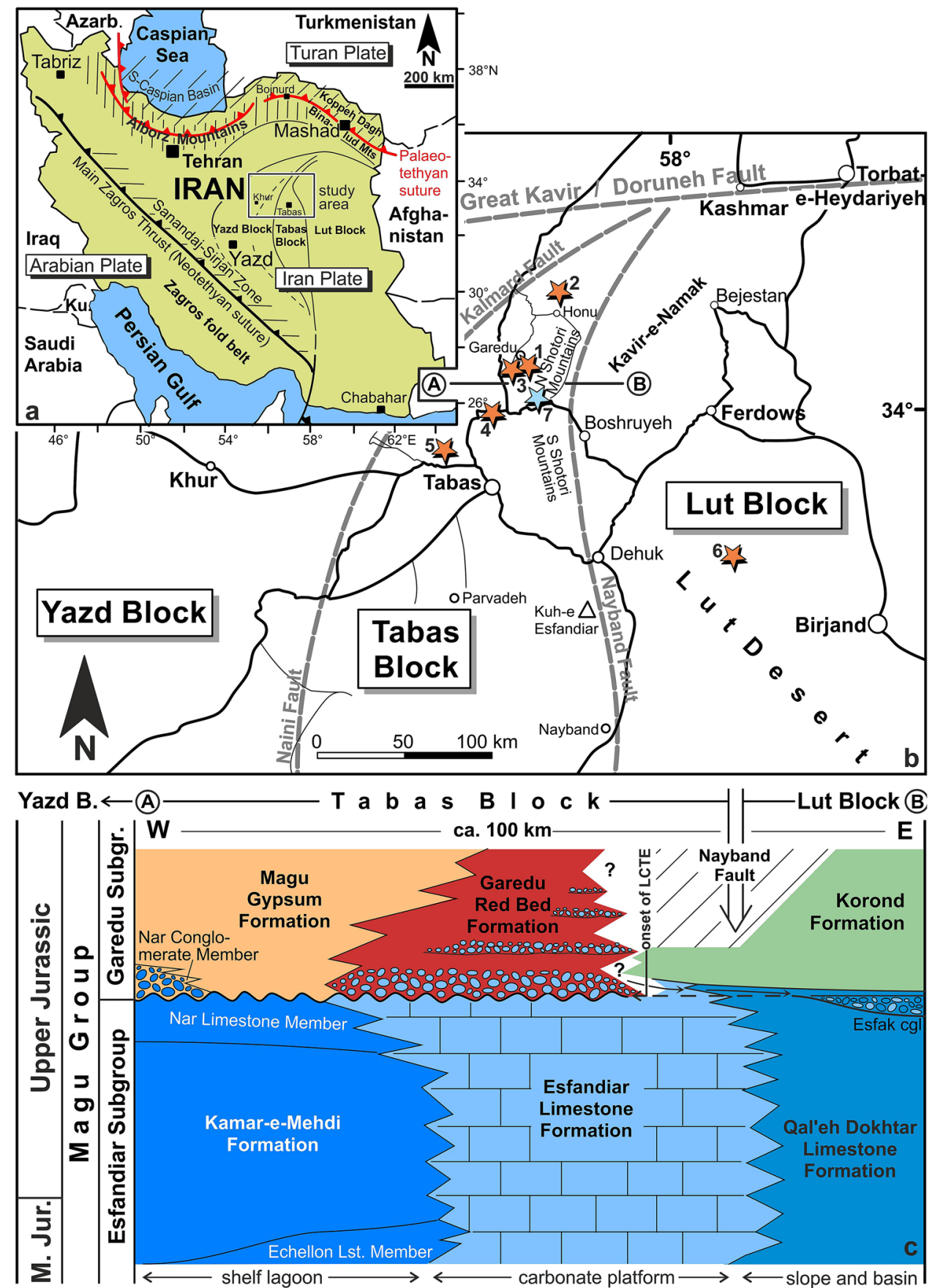

\section{Introduction}

Mesozoic, especially Jurassic rocks are very widespread in east-Central Iran and superbly exposed. As a geological unit, the area is part of the Iran Plate and consists of the Central Iranian blocks, i.e. the Yazd, Tabas, and Lut blocks (Fig. 1a). The geological reconnaissance of the Tabas Block was initiated with mapping surveys in the 1960s and 1970s (e.g., Huckriede et al. 1962; Stöcklin et al. 1965; Ruttner et al. 1968, 1970; Aghanabati 1977; Kluyver et al. 1983a, b). The thick Upper Triassic to Jurassic succession of this hitherto geologically largely unknown area was subdivided into several formations that were subsequently merged into two groups, the Upper Triassic to lower Middle Jurassic Shemshak Group and the Middle to Upper Jurassic Magu Group (northern Tabas Block) or Bidou Group (southern Tabas Block), respectively (cf. Aghanabati 1977, 1998; Seyed-Emami 1999). The Middle to Late Jurassic depositional megacycle of the Magu Group was terminated by a phase of tectonic instability known as the Late Cimmerian Tectonic Event (LCTE), the geodynamic 
background of which is still poorly understood. On the northern Tabas Block, the LCTE is reflected by the demise and tectonic dissection of the large-scale carbonate system of the Esfandiar Subgroup (Fürsich et al. 2003a; Wilmsen et al. 2009a, 2010), and the deposition of syntectonic sediments of the Garedu Red Bed Formation (GRBF; Ruttner et al. 1968) and its lateral equivalents, the Magu Gypsum Formation (Wilmsen et al. 2003). The Garedu Formation was recently put into focus again because, according to palaeomagnetic studies of Mattei et al. (2014), it reflects a massive southward plate shift. However, very little is known about the precise stratigraphic succession, facies, and depositional setting of this important lithostratigraphic unit and its implications for the geodynamic history of the Jurassic-Cretaceous boundary interval in the Middle East. Thus, an integrated stratigraphic-sedimentological study of the GRBF of the northern Tabas Block has been carried out and the results are evaluated in the framework of new geodynamic findings.

\section{Geological setting and stratigraphy}

\section{Plate tectonic and palaeogeographic framework}

The study area is located in the middle of the Central-East Iranian Microcontinent (CEIM; Takin 1972). The CEIM, Northwest Iran, as well as the Alborz and Binalud mountains form the Iran Plate, occupying a structural key position in the Middle East (Fig. 1a). As an element of the elongate Cimmerian terrane assemblage, it became detached from the northern margin Gondwana towards the end of the Palaeozoic Era (Late Permian) and collided with the southern margin of Eurasia (Turan Plate) during the early Late Triassic; the northward drift of the Cimmerian terranes closed the Palaeotethys Ocean and opened the Neotethys (e.g., Berberian and King 1981; Sengör et al. 1988; Sengör 1990; Saidi et al. 1997; Alavi et al. 1997; Stampfli and Borel 2002; Wilmsen et al. 2009b).

The CEIM consists of three structural units, from $\mathrm{E}$ to W the Lut, Tabas, and Yazd blocks, respectively, the long axes of which are today N-S-aligned (Fig. 1a, b). The spatial relationships of the three blocks during Jurassic times, however, are poorly known due to potential counterclockwise vertical-axis rotation of the CEIM of up to $135^{\circ}$ since the Triassic with respect to Eurasia (e.g., Soffel et al. 1996; Alavi et al. 1997; Besse et al. 1998; Cifelli et al. 2013; Mattei et al. 2015). However, during the Jurassic Period, the blocks were most likely in a pre-rotational position, their long axes approximately W-E-oriented and the Lut Block facing the Neotethys in the south (Wilmsen et al. 2009a, 2010; Mattei et al. 2015). Palaeogeographic and plate tectonic reconstructions for the late Middle Jurassic (Callovian, e.g., Thierry 2000; Barrier and Vrielynck 2008; Barrier et al. 2018) place the Iran Plate at the northern margin of the NeoTethys at subtropical palaeo-latitudes of ca. $20^{\circ}$ north. During Early Cretaceous times, rapidly subsiding small fringing oceans opened around the CEIM (Nain-Baft, Sabzewar and Sistan oceans; e.g., Tirrul et al. 1983; Nasrabady et al. 2011; Kazemi et al. 2019), probably in response to the onset of and/or accelerated counterclockwise vertical-axis rotation and the break-up of seep-seated faults along the margins of the microplate. These zones of crustal weakness developed into narrow oceanic areas during the course of the Early Cretaceous (Babazadeh and De Wever 2004; Pirnia et al. 2020), regarded supra-subduction oceans or peri-Neotethyan branches (Nasrabady et al. 2011; Kazemi et al. 2019; Pirnia et al. 2020). Palaeomagnetic data show that vertical axis rotations in Central Iran also played a significant role in accommodating the succeeding Arabia-Eurasia convergence (Mattei et al. 2020) that also led to the closure of the narrow oceanic basins fringing the CEIM during the latest Cretaceous to Paleogene (e.g., Omrani et al. 2013; Delavari et al. 2014; Kazemi et al. 2019).

\section{Lithostratigraphy}

The Upper Bajocian to Upper Jurassic Magu Group (Aghanabati 1977, 1998) of the northern Tabas Block is characterized by a pronounced lithological variability that reflects the increased synsedimentary tectonic activity (Fürsich et al. 2003b; Seyed-Emami et al. 2004, 2020). Consequently, the Magu Group was subdivided into three subgroups based on laterally extensive (interregional) tectonic unconformities, i.e., the Upper Bajocian-Lower Callovian Baghamshah Subgroup, the Callovian-Kimmeridgian Esfandiar Subgroup, and the Kimmeridgian-Tithonian Garedu Subgroup (Wilmsen et al. 2003, further improved and expanded by Seyed-Emami et al. 2006 and Wilmsen et al. 2009a).

The Esfandiar Subgroup (Fig. 1c) documents a largescale, low-latitude carbonate system on the Tabas Block during the late Middle to early Late Jurassic (Fürsich et al. 2003b; Wilmsen et al. 2010). The Esfandiar Limestone Formation signifies a fault-block-related carbonate platform developing along the eastern crest of the tilted Tabas Block (Fürsich et al. 2003a). As a N-S-trending barrier it sheltered a large-scale shelf-lagoon on the hanging wall dipslope where fine-grained calcareous sediments accumulated (Kamar-e-Mehdi Formation; Wilmsen et al. 2010, Fig. 1c). The eastern margin of the Esfandiar Platform was controlled by synsedimentary tectonics of the Nayband Fault which forms the boundary between the Tabas and the Lut Block. The adjacent slope and basinal area to the east received large amounts of platform-derived material that constitute the Qal'eh Dokhtar Limestone Formation (Fig. 1c; Schairer 
et al. 2000, 2003). The end of this carbonate system was heralded by the onlap of the basinal Korond Formation onto the eastern parts of the Esfandiar Platform in the southern Shotori Mountains around the Oxfordian-Kimmeridgian boundary, coinciding with an apparent cut-off of the shelf lagoon from the open sea (Wilmsen et al. 2010), and the onset of Garedu Red Bed deposition in the northern Shotori Mountains.

The Garedu Subgroup, named after the GRBF (Ruttner et al. 1968), is dominated by limestone conglomerates, red siltand sandstones, and gypsum deposits with siliciclastic intercalations (Fig. 1c). Apart from the eponymous formation, the Garedu Subgroup originally contained only one other formation, i.e. the Magu Gypsum Formation of Aghanabati (1977), but new data suggest that the Korond Formation is largely a lateral equivalent of the GRBF. The GRBF crops out in the northern Shotori Mountains, where it unconformably rests on the Esfandiar or Qal' eh Dokhtar Limestone formations, while the Magu Gypsum Formation characterizes the western part of the Tabas Block where it sharply overlies the restricted Nar Limestone Member of the Kamar-e-Mehdi Formation (Wilmsen et al. 2010; Zamani-Pedram 2011). We consider the GRBF as a formal unit despite the fact that Ruttner et al. (1968, p. 92) regarded their unit as informal because they suggested that a type section should be selected farther to the south, in the southern part of the Tabas Block, where equivalent uppermost Jurassic (to lowermost Cretaceous) strata are thicker and more fossiliferous. However, these strata have been termed Ravar Formation by Huckriede et al. (1962). Both areas of distribution are widely separated and lithologically distinct so that a perpetuation of the GRBF is advised. Furthermore, Ruttner et al. (1968, pp. 91-100) presented a detailed description of their Garedu Red Beds including two measured sections from the type area east of the Garedu lead mine.

\section{Bio- and chronostratigraphy}

Biostratigraphic data from the Garedu Formation are very sparse and the chronostratigraphic classification has mostly been done by stratigraphic superposition and interpolation of data from laterally equivalent formations. Ruttner et al. (1968) reported calcareous algae of inferred Kimmeridgian-Tithonian age from the GRBF, but the mentioned taxa are not very age-diagnostic and the identifications are not supported by illustrations. However, in its type area in the northern Shotori Mountains, the formation partly overlies with gradual contact the Esfandiar and Qal'eh Dokhtar Limestone formations (Ruttner et al. 1968). Both formations have been dated to range from the Callovian into the Oxfordian-Kimmeridgian boundary interval (Schairer et al. 2000, 2003; Fürsich et al. 2003a; Bagi and Tasli 2007 suggest an Early Kimmeridgian age for the top of the Esfandiar Limestone Formation at the type section, to the south of the Shotori Mountains). The in part gradual basal contacts of the GRBF (also observed in this study) are important because they suggest that the change in depositional style from carbonate platform to syntectonic clastics occurred around the Oxfordian-Kimmeridgian boundary or in the earliest Kimmeridgian and is not associated with a significant stratigraphic gap. There is no information on the age of the upper GRBF and no complete successions exist. However, according to Zamani-Pedram (2011), the age of the Magu Gypsum Formation, the lateral equivalent of the GRBF, is Kimmeridgian to Berriasian-Valanginian.

\section{Material and methods}

Three sections and several additional sites in the northern Shotori Mountains of east-Central Iran exposing the GRBF have been visited, logged bed-by-bed and sampled in great detail using a modified Jacob's staff (cf. Sdzuy and Monninger 1985), applying standard palaeontological and sedimentary field methods (e.g., Goldring 1999; Stow 2005). Our field approach includes bed-by-bed logging at a dmscale with grain-size and component analyses using a handlens, evaluation of sedimentary structures, recording of body and trace fossil contents accompanied by taphonomic observations, the mapping of stratigraphic geometries and the study of stratal architectures as well as tracking of key surfaces (such as unconformities). Fifty thin-sections have been prepared from characteristic lithofacies identified in the field and studied using a Leica M125 stereo-microscope with a Leica DFC 420 digital camera capturing images in the optical pathway. The classification of carbonate rocks follows Dunham (1962) with subsequent modifications by Embry and Klovan (1971). Thin-sections are stored in the palaeozoological collections of the Museum für Mineralogie und Geologie (MMG), Senckenberg Naturhistorische Sammlungen Dresden (SNSD), repository MMG: AsK).

\section{Results}

\section{Sections and studied sites exposing the Garedu Subgroup}

\section{Type area at Garedu mine}

An almost 200-m-thick section has been logged in the type area of the formation, ca. $2.5 \mathrm{~km}$ east-southeast of the Garedu lead mine, at the western flank of the northern Shotori Mountains (no. 1 in Fig. 1b, N 34 14'19", E 57 07'16"; Figs. 2a, 3a). There, the Garedu Red Bed Formation (GRBF) is exposed in two narrow, $\mathrm{N}-\mathrm{S}$-trending faulted synclines between anticlinal ridges formed by the Qal'eh Dokhtar Limestone or Esfandiar Limestone Formation. Our section 
corresponds to section B (western limb) of Ruttner et al. (1968), who already noted a pronounced facies and thickness asymmetry in the syncline displayed by the GRBF: the western limb is more than three-times thicker and characterized by thick conglomerate units in the lower 100-150 m that are missing in the eastern limb. During our field survey, we could confirm the facies asymmetry even though we did not log a section in the eastern limb. The contact to the underlying carbonates of the Esfandiar Limestone Formation is poorly exposed, but the intercalation of conglomeratic limestone beds in the uppermost part consisting of oolitic grainstones and fine-bioclastic wackestones indicates interfingering of platform carbonate and conglomerate deposits at the junction of both formations. A 16-m-thick, massive, poorly sorted pebble to cobble conglomerate of angular to sub-rounded Qal'eh Dokhtar and Esfandiar Limestone clasts within a reddish sandy matrix characterizes the lower GRBF (Fig. 3a). Occasionally, carbonate clasts may reach up to $0.8 \mathrm{~m}$ in diameter. The basal conglomerate is followed by a ca. 40-m-thick unit of bedded intraclastic and nodular limestones with limestone-conglomerate intercalations (Fig. 2b, c) and red sandstone beds. Oyster shell beds indicate at least some marine influence, contrasted by reddish colours, vugs and pedogenic features such as caliche horizons (Fig. 2d). From the $65-\mathrm{m}$-level of the measured section, siliciclastic facies prevails up to $146 \mathrm{~m}$ and reddish fine-grained sandstones with intercalated, sharp-based, partly graded or crudely cross-bedded conglomerate and breccia beds predominate (Fig. 3a). The fine interbeds show occasional caliche horizons and rare nodular sandy carbonate beds. The uppermost part of the section is sand-dominated with only subordinate thin and fine conglomerate intercalations. Nine thin-sections (000307-1-9) have been prepared from characteristic lithofacies identified in the field.

\section{Section north of Honu}

The measured section north of Honu, in the northernmost part of the northern Shotori Mountains (no. 2 in Fig. 1b, N

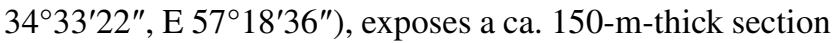
of the upper Esfandiar Limestone Formation and the lower GRBF (Figs. 2e, 3b). Thirty-two metres of the upper Esfandiar Limestone Formation have been logged, comprising medium-grey intraclastic grainstones and mudstones, partly with fenestral fabrics. Towards the top, pedogenic and rhizolitic fabrics are common. The GRBF rests unconformably on the carbonates, starting with thick, crudely trough crossbedded, reddish conglomerates consisting of rounded Esfandiar pebbles and cobbles in a silty matrix, intercalated with reddish sandstone and limestone beds, the latter partly with microbial fabrics. Approximately $30 \mathrm{~m}$ above the contact, the strata get finer and brick-red intercalation of fine-grained silty sandstones and sharp-based, pebbly sandstones prevails
(Fig. 2f). In the uppermost part of the measured section, another 15-m-thick conglomerate unit was logged (Fig. 3b). Occasional imbrication of pebbles and cobbles in the conglomeratic layers suggests a sediment transport from SW to NE. Fifteen thin-sections (020213-1-15) have been prepared from characteristic lithofacies, identified in the uppermost Esfandiar Limestone Formation and the GRBF.

\section{Ozbak-Kuh}

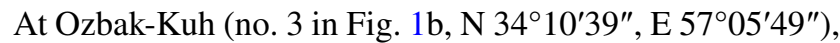
the GRBF overlies the Qal'eh Dokhtar Limestone Formation. It consists of ca. $100 \mathrm{~m}$ of bedded, dm- to m-thick pebble-cobble conglomerates that grade up-section into finer-grained (sandy) red beds with intercalated, sharpbased, lenticular pebbly sandstones and conglomeratic limestones that are occasionally graded or show low-angle cross-stratification and horizontal lamination. The limestone clasts are derived from the underlying Qal'eh Dokhtar Formation, comprising micrites, intraclastic and oolitic grainstones, bioclastic rudstones and crinoid grainstones. Also, red sandstone clasts have been observed as components within the conglomeratic unit, especially in its upperparts. Towards the top of the succession, brick-red, fine-grained sandstones with trough cross-bedding and small channels and structureless fine-sandy siltstones predominate. Metrescale cycles from siltstone to micritic carbonates occur in this part, and occasionally oncolitic and microbial fabrics have been observed in the carbonates. The exposure situation did not allow the logging of a continuous section, but characteristic facies types have been sampled (thin-sections 000229-1-9).

\section{Kuh-e-Talkhori and Kuh-e-Mehregani}

At Kuh-e-Talkhori (no. 4 in Fig. 1b, N 33 $59^{\prime} 28^{\prime \prime}$, E $\left.56^{\circ} 51^{\prime} 39^{\prime \prime}\right)$, an unequivocal interfingering of the Esfandiar Limestone Formation and the GRBF has been observed. The change from carbonate platform deposition to siliciclastics starts with brownish sandstone beds that contain scattered cobbles of Esfandiar limestone up to $15 \mathrm{~cm}$ in diameters. The following $50 \mathrm{~m}$ are characterized by an intercalation of marine limestone beds of Esfandiar type, red sandstones, conglomeratic siltstones, and pebbly oolitic grainstones. The succession grades into fine-grained red beds (reddish siltstones) up-section. Due to faulting, no continuous section could be measured, but six thin-sections represent the observed facies types (samples 010225-12/1-6).

At Kuh-e-Mehregani (no. 4 in Fig. 1b, N 33 $58^{\prime} 42^{\prime \prime}, \mathrm{E}$ $56^{\circ} 54^{\prime} 14^{\prime \prime}$ ), an interfingering of carbonate platform and red bed deposition has also been recorded (field observations only). Oncoidal, micritic and oolitic-bioclastic limestones are intercalated with yellow-brownish to reddish, 


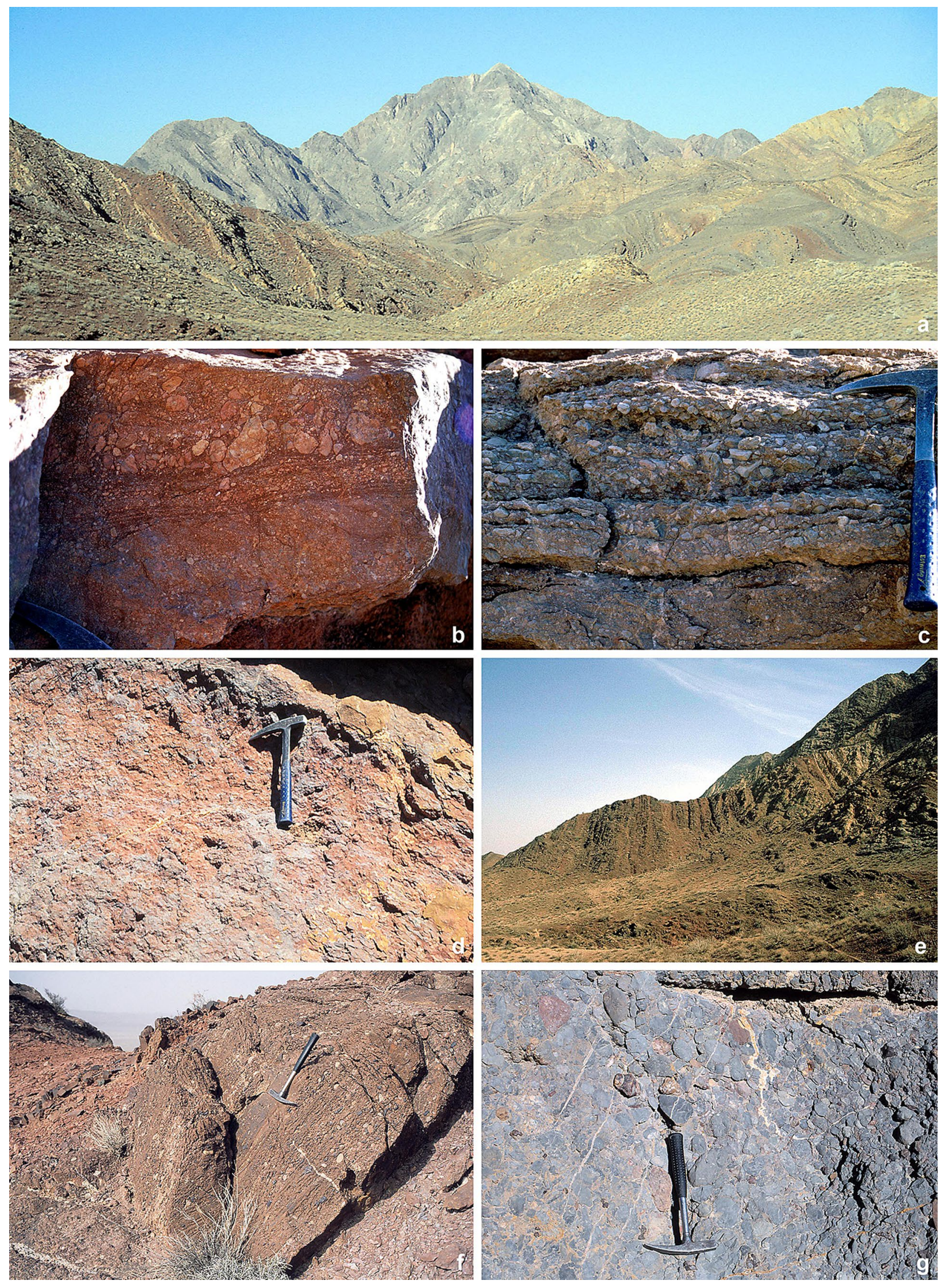


४Fig. 2 Field aspects. a Type section of the Garedu Red Bed Formation (GRBF) east of the Garedu mine (view to the northeast; the peak in the background is Kuh-e-Bam, formed by rocks of the Esfandiar Limestone Formation). b Limestone conglomerate with reddish sandy matrix (facies type FT-1b) from the lower part of the GRBF in the type section at ca. $62 \mathrm{~m}$. c Limestone conglomerate with calcareous matrix (facies type FT-1a) from the lower part of the GRBF in the type section at ca. $50 \mathrm{~m}$. d Red silt- to fine-grained sandstone intercalation (facies type FT-4) with caliche concretions grading into a nodular limestone bed (facies type FT-4) at top (GRBF at the type section, 57.5-59 m). e Steeply west-dipping GRBF overlying the Esfandiar Limestone Formation to the right in the section north of Honu (view to the north). f Sharp-based, trough-cross-bedded, pebbly, medium- to coarse-grained fluvial channel sandstone (facies type FT-2, section north of Honu, base at ca. $82.5 \mathrm{~m}$ level). g Kuh-e-Birg conglomerate at Kuh-e-Birg; note the predominance of dark limestone clasts (mainly Qal'eh Dokhtar Limestone Formation) as well as subordinate chert and red sandstone clasts (left above hammer; facies type FT-1b)

thin-bedded fine-grained sandstones and siltstones as well as brownish dolostones and fine-grained limestone conglomerates. Ruttner et al. (1968, p. 98) also report a lateral transition of reddish sandstone into greenish and grey marls and sandy limestones.

\section{Type section of the Nar Conglomerate}

The type section of the Nar Conglomerate Member of the lower Magu Gypsum Formation is situated in the Echellon area, NW of Tabas (no. 5 in Fig. 1b, N 33 49'04", E 56 36'19"; Fig. 4). It overlies restricted mud-/wackestones and thin red siltstones of the Nar Limestone Member of the Kamar-e-Mehdi Formation, which contain ostracods and agglutinated foraminifers (Alveosepta jaccardi). A 4-m-thick package of red siltstone forms the lowermost bed of the Magu Gypsum Formation, followed by a 7-m-thick, inversely graded conglomerate with a reddish matrix of coarse-grained sand and small angular limestone chips. The components are derived from the Kamar-e-Mehdi Formation, predominantly the Nar Limestone Member, are poorly to moderately well rounded, and reach up to $30 \mathrm{~cm}$ in diameter. Four thin-sections from Nar Limestone Member (990228-10, -11/1-3) and thinsection 000310-8 from the matrix of the Nar Conglomerate Member complement the measured section (Fig. 4).

\section{Kuh-e-Birg}

Kuh-e-Birg is a remote isolated inselberg, ca $80 \mathrm{~km}$ east of the Shotori Mountains on the Lut Block, surrounded by Neogene desert deposits (no. 6 in Fig. 1b, N 33 17'15", E 58 19'29"; field observations, thin-Section 020208-4). There, the Qal'eh-Dokhtar and Esfandiar Limestone formations are unconformably overlain by a conglomerate unit informally termed "Kuh-e-Birg conglomerate" (Lotfi 1995;
Fig. 2g). At Kuh-e-Birg, the Esfandiar Limestone Formation is strongly dolomitized and contains chert nodules. A 0.8-m-thick coarse conglomerate with rounded cobbles and boulders up to $30 \mathrm{~cm}$ in diameter forms the basal bed of the Kuh-e-Birg conglomerate. Up-section, decimeter- to meterthick pebble to cobble conglomerates intercalate with red, calcareous, medium- to coarse-grained sandstones of similar thickness containing bioclasts (predominantly of oysters) and some indeterminate trace fossils. The conglomerate beds consist of well-rounded clasts of Qal'eh Dokhtar and Esfandiar provenance (in the latter cherts are common) within a calcareous to sandy-calcareous matrix; as subordinate components, red sandstone clasts occur (Fig. 2g). Occasionally, sandy-pebbly oyster shell beds are intercalated. Up-section, grain size decreases, while sorting of components increases. The thickness of the Kuh-e-Birg conglomerate is at least $200 \mathrm{~m}$.

\section{Facies types of the Garedu Red Bed Formation (GRBF)}

The facies analysis of the GRBF is based on the evaluation of litho- and microfacies, supplemented by field observations of features such as bedding, sedimentary structures as well as trace and body fossils. Based on the integrated data, the investigated strata have been grouped into 12 facies types (including two subtypes) that are briefly described in Table 1 and illustrated in Figs. 2, 5, 6 and 7. Thin-section photomicrographs are shown according to their original stratigraphic orientation, i.e., up-section corresponds to the page top.

Limestone conglomerates and/or breccias with calcareous (FT-1a) and sandy (FT-1b) matrix are the most conspicuous facies type of the GRBF. They are predominantly clast-supported and component sizes range from granules to boulders. The thickness of individual beds (that may be unor normally graded) reaches up to ten metres. In general, a fining- and thinning-upward trend is seen in the sections and the conglomerate beds are replaced up-section by brick-red to brownish, sharp-based, cross-bedded pebbly sandstones and sandstones of FT-2 and FT-3. In the lower part of the formation, limestone intercalations, partly with marine fossils, are not uncommon, while in the middle and upper part thick units of rather homogeneous red silt- to fine-grained sandstones from the interbeds of the sharp-based coarser intercalations of FT-1-3. At Kuh-e-Birg, bioclastic sandstones with occasional oyster shell beds and other marine body and trace fossils (FT-5) are intercalated between sandy limestone conglomerates of FT-1b. The carbonate facies of the GRBF includes litho- and bioclastic sparitic rudstones (FT-6) that may be transitional to sparite-cemented limestone conglomerates of FT-1a, and microbialites (FT-7) that fill the interstices between large components in the upper part of conglomerates and/or cover conglomeratic beds. 

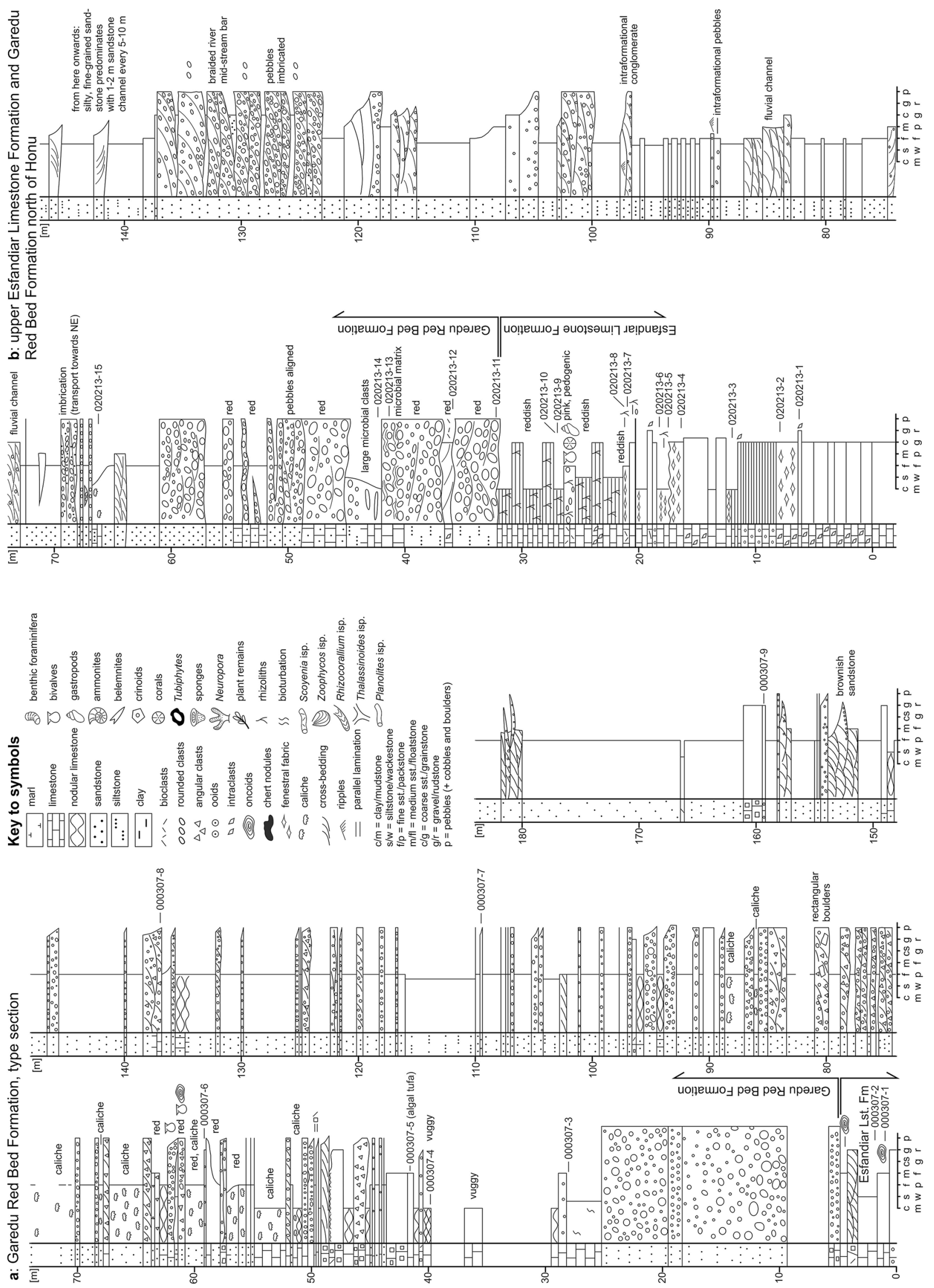
4Fig. 3 Measured sections including key to symbols (applies also for other figures). a Type section of the Garedu Red Bed Formation (GRBF) near Garedu mine in the northern Shotori Mountains (no. 1 in Fig. 1b). b Section of the uppermost Esfandiar Limestone Formation and the GRBF north of Honu (no. 2 in Fig. 1b)

Additional carbonate facies types include floatstones with oncoids formed by weakly calcified oscillatoriacean cyanobacteria (FT-8), algal tufas (FT-9) and characean wackestones with small gastropods and ostracods (FT-10). Pedogenic carbonates with caliche features (nodular, coalescent fabrics) and rhizolites (FT-11) are common in the otherwise structureless reddish silt- and fine-grained sandstones of FT-4. These pedogenic carbonates are associated with pisolitic and lithoclastic rudstones (FT-12).

\section{The Esfak conglomerate}

The Esfak conglomerate is a spectacular stratigraphic feature in the upper part of the Qal'eh Dokhtar Limestone Formation west of Esfak (no. 7 in Fig. 1b, N 34 02'57", E $57^{\circ} 10^{\prime} 00^{\prime \prime}$; Figs. 8, 9). It is included in this work, because presumably it records the basinal signal of the onset of Garedu Red Bed deposition in the adjacent northern Shotori Mountains, highlighting the considerable impact of the tectonic processes terminating the carbonate system of the Esfandiar Subgroup. Apart from a detailed log (Fig. 9), four thin-sections (000305-2-5) have been sampled from the conglomeratic facies of the Qal'eh Dokhtar Limestone Formation. They were evaluated (e.g., for component analysis) but of course not included in the facies reconstruction of the GRBF.

The Esfak conglomerates comprise a lenticular, up to 70-m-thick unit of limestone conglomerates, which cut into the upper part of the Qal'eh Dokhtar Limestone Formation that consists of basinal facies at that locality (300-400-m-thick spiculitic to filamentous marly mudstones with rare calcified radiolaria and Chondrites isp., the upper $205 \mathrm{~m}$ of which have been logged; thin-sections 000222-1, -13) up to the unconformable base of the conglomerates which cut several decametres into the substrate (Fig. 8a, b). Below the contact, poorly preserved taramelliceratid ammonites of Oxfordian affinity have been found. The basal bed of the channel unit is a 6-m-thick, graded, clast-supported boulder- to cobble-conglomerate with angular to sub-rounded limestone clasts mainly consisting of different facies types of the Qal'eh Dokhtar Limestone Formation (Fig. 8c). Up-section, thin-bedded, fine-grained wackestones and a few graded allodapic limestones form an 8-m-thick non-conglomeratic intercalation. Four more of these decametre-scale conglomerate-to-mud-/wackestone cycles follow up to the $70 \mathrm{~m}$ level. Slumping structures and scattered limestone boulders in the fine-grained intervals indicate mud-flow deposition. A 5-m-thick olisthostrome at 38-43 m (Fig. 9) contains blocks up to $4 \mathrm{~m}$ in diameter consisting of Esfandiar platform facies (e.g., coral boundstone, light-grey mudstones). From the $70 \mathrm{~m}$ level onwards, the conglomerates disappear and a fining- and thinning-upward succession of allodapic limestones and (marly) wackestones follows up to the $133 \mathrm{~m}$ level at which, along a minor fault, the monotonous olivegreen marls of the Korond Formation follow (Fig. 9). This unit yielded in its lower part ammonites of the Early Kimmeridgian Platynota to Hypselocyclum zones (Sowerbyceras silenum, Orthosphinctes ex gr. polygyratus, Orthosphinctes (Ardescia) sp., Subdiscosphinctes sp.; cf. Schairer et al. 2003; Seyed-Emami et al. 2020), continues eastwards onto the Lut Block for a considerable distance and reaches a thickness of at least 500-1000 m.

\section{Discussion}

\section{The age of the strata}

The age of the Garedu Red Bed Formation (GRBF) is poorly constrained by biostratigraphy and, unfortunately, our study cannot add any new biostratigraphic data. The calcareous algae of inferred Kimmeridgian to Tithonian age reported from the GRBF of the northern Shotori Mountains (Ruttner et al. 1968) are not age-diagnostic and the data cannot be reproduced due to the lack of any illustration. However, owing to the very much improved biostratigraphic dating of, and enhanced understanding of the lateral relationships to other formations in the Esfandiar and Garedu subgroups of the Tabas Block (see Wilmsen et al. 2009a and SeyedEmami et al. 2020 for details), biostratigraphic data can be interpolated and the chronostratigraphic position of the GRBF can be approximated with adequate precision.

The reported interfingering of the GRBF with the Baghamshah Formation (Ruttner et al. 1968, p. 92) is related to the confusion of this Bathonian to Lower Callovian unit, which underlies the Esfandiar Subgroup, with the lithologically almost identical and homochromatic Kimmeridgian to Tithonian Korond Formation, which overlies the Esfandiar and Qal'eh Dokhtar Limestone formations at the eastern margin of the Tabas Block (Fürsich et al. 2003a; Schairer et al. 2003). This observation is important as it clearly demonstrates that the Korond Formation is a lateral equivalent of the GRBF and allows estimating its age by interpolation of data from a lateral, ammonite-calibrated unit.

In the southern Shotori Mountains, the Korond Formation onlaps the Esfandiar Limestone Formation along a regional latest Oxfordian-earliest Kimmeridgian drowning unconformity that has already been related to tectonic processes by Fürsich et al. (2003a). Correlation via the Esfak 


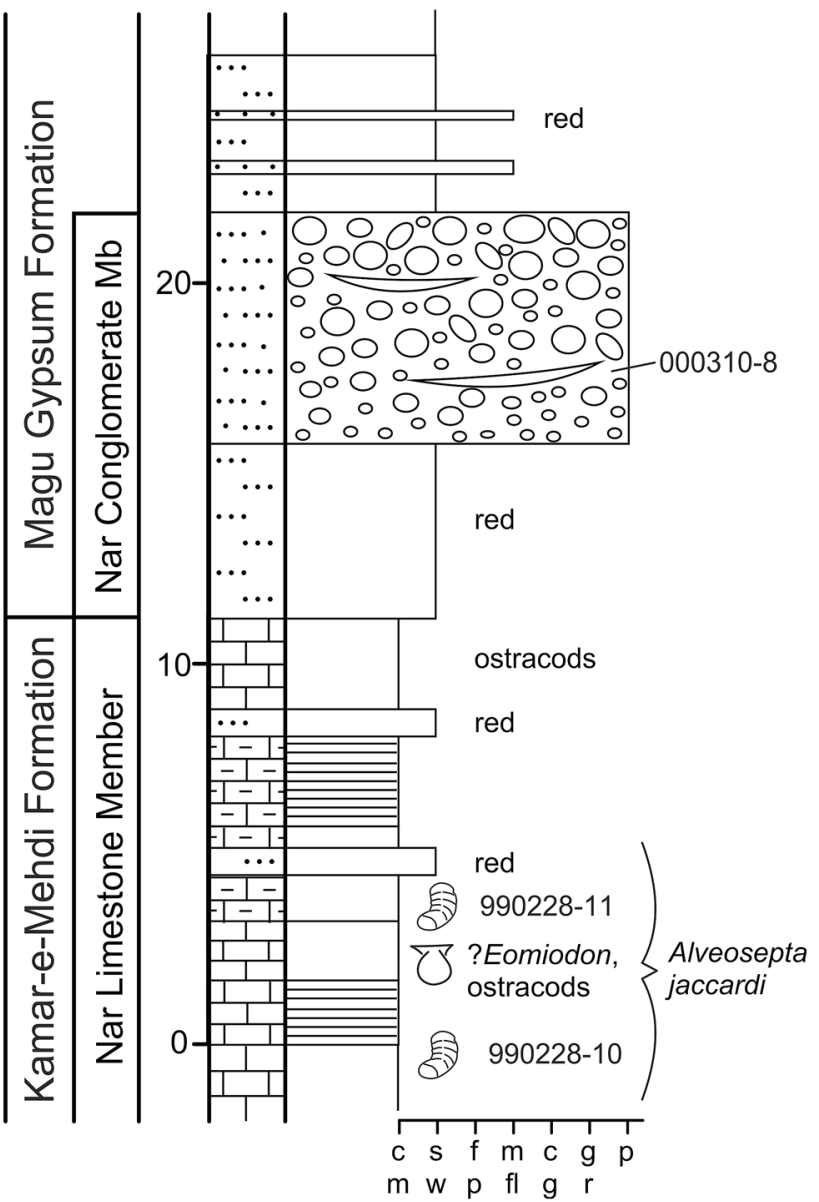

Fig. 4 Type section of the Nar Conglomerate Member of the Magu Gypsum Formation in the Echellon area (no. 5 in Fig. 1b)

conglomerates, likewise emerging as a latest Oxfordian-earliest Kimmeridgian feature, links this tectonic event to the onset of Garedu Red Bed deposition in the northern Shotori Mountains. Ammonite evidence so far indicates only a Kimmeridgian age for the Korond Formation (Schairer et al. 2003). However, a Rostroperna shell (sample 0202043 ) from the upper Korond Formation in the type area near Quassem-Abad has a $\delta^{87} \mathrm{Sr}$ ratio of $0.707080 \pm 0.000007$, which corresponds to a Tithonian age (McArthur et al. 2001; Wierzbowski et al. 2017). Furthermore, the occurrence of the benthic foramínifer Everticyclammina cf. virguliana from the upper Korond Formation in the type area near Quassem-Abad (thin-sections 020204-1 and -6) may also indicate a younger (Kimmeridgian-Berriasian) age (Bassoullet 1997).

When tracing the tectonic signal of the onset of Garedu Red Bed deposition into the shelf lagoonal setting of the Esfandiar Subgroup carbonate system, the occurrence of the Late Oxfordian to early Late Kimmeridgian benthic foraminifer Alveosepta jaccardi (cf. Bassoullet 1997) in the uppermost part of the Kamar-e-Mehdi Formation (i.e., at the top of the Nar Limestone Member), just below the Nar Conglomerate Member of the Magu Gypsum Formation, is of significance (Wilmsen et al. 2010). Considering the stratigraphic position between the Nar Limestone Member below and transgressive mid-Cretaceous strata above in the Kuhe-Qoleh Nar section (Zamani-Pedram 2011), the age of the Magu Gypsum Formation, i.e. the lateral equivalent to the GRBF, is (Late) Kimmeridgian to Berriasian-Valanginian.

In a nutshell, the change in depositional style from carbonate platform to syntectonic clastics occurred on the northern Tabas Block around the Oxfordian-Kimmeridgian boundary and/or in the earliest Kimmeridgian and is not associated with a significant stratigraphic gap. The age of the GRBF is thus Kimmeridgian to Tithonian but a stratigraphic range into the earliest Cretaceous cannot be excluded.

\section{Depositional environment}

The GRBF of the northern Tabas Block represents a lithologically variable unit combining a complex suite of predominantly continental facies types (Table 1; Figs. 5, 6, 7). The maximum thickness of the formation in the study area is unknown because no complete sections exist. However, it certainly exceeded five hundred metres and varies considerably over short distances (Ruttner et al. 1968 logged $474 \mathrm{~m}$ on the western limb in the Garedu syncline of their "B section", while on the eastern limb section only $131 \mathrm{~m}$ were measured).

The lower part of the GRBF consists of coarsely bedded and poorly sorted pebble- to boulder-conglomerates (occasionally breccia, FT-1) with a sandy matrix and/or calcareous cement, unconformably or gradually overlying the Esfandiar and Qal'eh Dokhtar Limestone formations. The components are overwhelmingly limestone lithoclasts exclusively derived from the two formations; in the Nar Conglomerate of the basal Magu Gypsum Formation, the underlying Nar Limestone of the Kamar-e-Mehdi Formation supplied most of the components. Red sandstone clasts occur subordinately and indicate intraformational reworking of red beds. The limestone conglomerates are interbedded with calcareous sandstones containing oyster fragments/shell beds and litho-/bioclastic rudstones (FT-5 and FT-6) as well as algal tufas, characean wackestones, oncolitic floatstones and microbialites (FT-7-10). The conglomerates indicate uplift and reworking of lithified strata of the Esfandiar Subgroup and parauthothonous deposition in small basins in form of alluvial fans that in part interfinger with marginal marine (marine to brackish skeletal components such as echinoderms and oysters) and freshwater depositional environments (ponds or small lakes with microbial sediments, characean muds and algal tufas; Fig. 10). The massive to poorly graded and only crudely bedded coarse pebble to boulder conglomerates in the lower GRBF recorded at Honu 


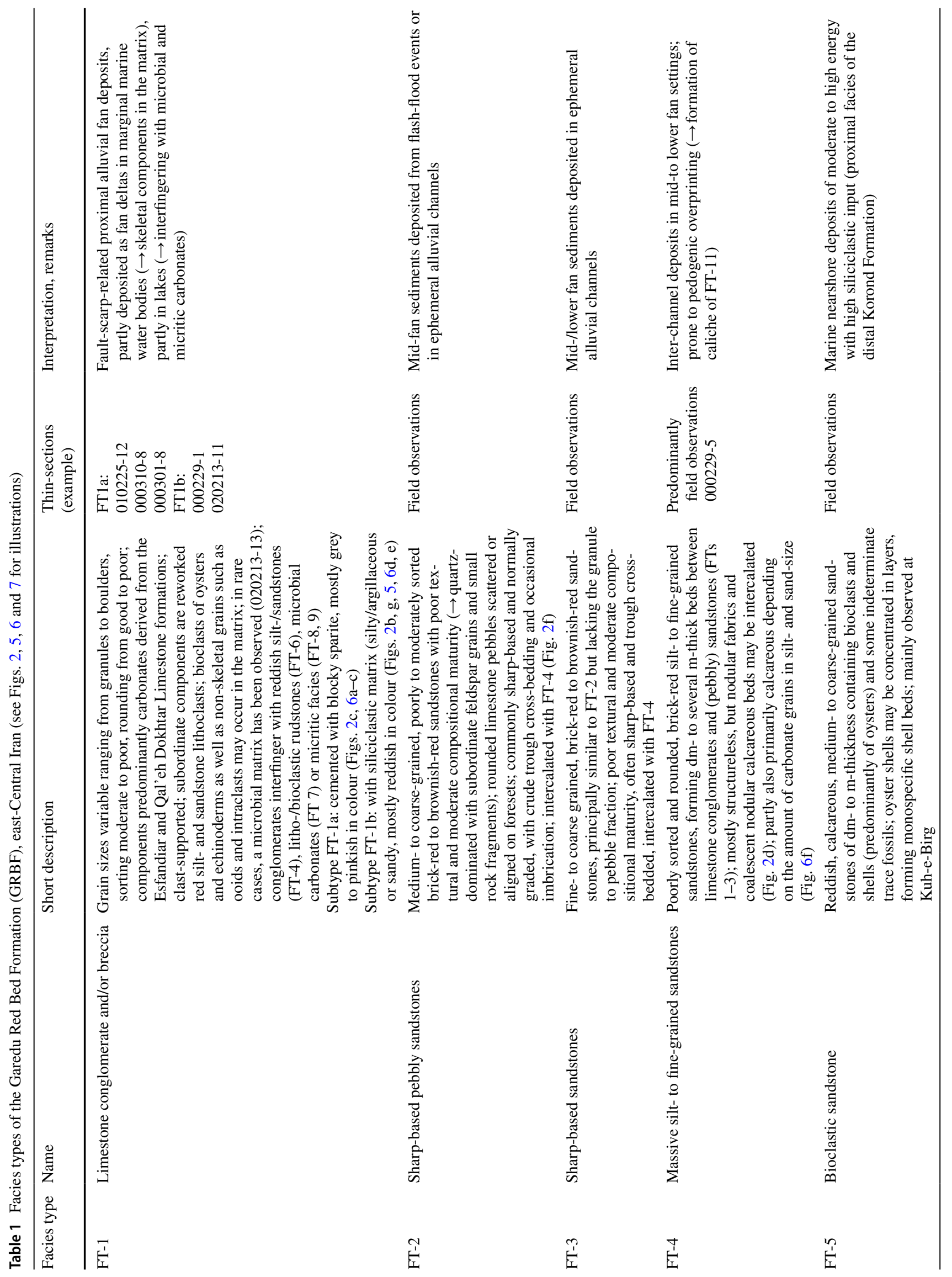




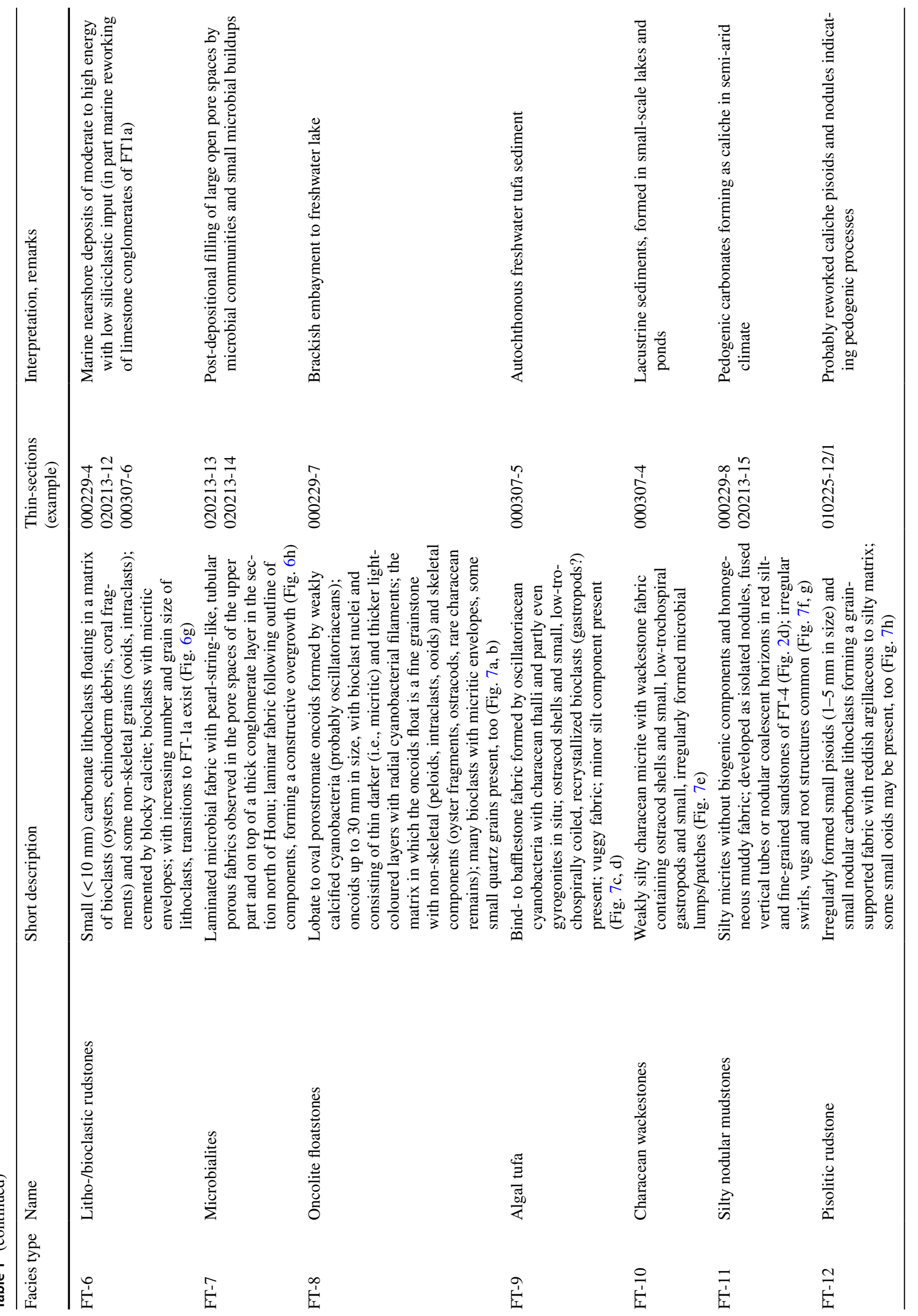


and in the type area represent proximal alluvial fan deposits (cf. Galloway and Hobday 1996) that partly have been shed into standing bodies of water as small-scale fan deltas (cf. McPherson et al. 1987, 1988). These water bodies were either marginal marine high-energy zones (e.g., in Honu, where the lowermost conglomerate bed is overlain by lithoand bioclastic floatstones of FT-6, sample 020213-1) or freshwater lakes as indicated by the direct superposition of conglomerates by lacustrine carbonates (FT-7-10) (Fig. 10). Lakes may be common in strike-slip settings (see geodynamic discussion below) where high subsidence rates prevail and complex fault patterns provide many enclosed potential lake basin sites (Platt and Wright 1991), provided surface and/or groundwater influx is sufficient (Gierlowski-Kordesch 2010). Another important requirement for the formation of lacustrine carbonates, i.e. the availability of carbonates for weathering in the catchment area and subsurface to produce lake carbonates (Gierlowski-Kordesch 2010), is also fulfilled with the carbonate strata of the Esfandiar Subgroup providing extensive bedrocks (Fig. 10). Characean wackestone, microbialites, and algal tufas are common lacustrine carbonate facies in littoral to sublittoral settings of (perennial) lakes (Platt and Wright 1991; Gierlowski-Kordesch 2010) and microbial fabrics similar to the ones observed in FT-7 have been reported from thrombolitic microbial mounds in the Mupe Member of the Lulworth Formation (Jurassic-Cretaceous boundary interval, southern England) that formed at the margins of a brackish lake (Gallois et al. 2018).

Especially in the lower part of the GRBF there is a considerable lateral variation in thickness and facies indicating fault-controlled deposition in a closely spaced array of uplifted and downthrown blocks (typically occurring in strike-slip settings; e.g., Nilsen and Sylvester 1995). Up-section, conglomerate intercalations become rarer and thinner, and sharp-based, medium- to coarse-grained, occasionally pebbly sandstones and red silt-/fine-grained sandstones of braided river origin such as gravel bars, channel fills, floodplain fines (cf. Miall 1977; 1996) predominate. However, also the sharp-based medium- to coarse-grained sandstone intercalations become less common up-section and fine-grained reds beds of FT- 4 prevail. Thus, the facies of the Garedu Red Bed Formation shows an overall finingupward trend, from limestone conglomerates below to finegrained red beds above. The source area for the red beds of the GRBF was most likely the Kolut-e-Morad Kosh Massif that delimits the outcrop belt of the formation in the west (Figs. 10, 11) and where, after unroofing of the Esfandiar Subgroup carbonates, thick sequences of (today slightly metamorphic) siliciclastics of the Shemshak Group are exposed. The red colours of the GRBF and pedogenic features such as calcretes suggest arid to semi-arid conditions (e.g., Walker 1967; Sheldon 2009). Similar calcretes, commonly with micritic fabrics, are common in the middle part of the roughly time-equivalent red beds of the Shurijeh Formation of the Koppeh Dagh Mountains in northeast Iran (Moussavi-Harami et al. 2009). The pisolitic and lithoclastic rudstones (FT-12) indicate the reworking of pedogenic carbonates (calcretes) into parautochthonous lags.

The asymmetric facies distribution in the Garedu type area with conglomerates predominating in the west and occasional imbrication of clasts indicate a principal sediment transport from west to east. Lateral interfingering of the predominantly continental Garedu Red Beds with the greenish sandy marls of the marine Korond Formation took place at the eastern margin of the Tabas Block (Fig. 10), as already noted by Ruttner et al. (1968) although they mistook these strata for the Baghamshah Formation. Towards the west, the GRBF finds a lateral equivalent in the predominantly fine-grained siliciclastics and evaporites of the Magu Gypsum Formation (Fig. 10) that represents a playalike sedimentary environment (Zamani-Pedram 2011). The basal coarse-grained Nar Conglomerate of the Echellon area is similar to the conglomerates in the lower Garedu Red Bed Formation but must have been derived from the west, i.e. the boundary area between the Tabas and the Yazd blocks (Figs. 10, 11).

\section{Geodynamic significance}

The onset of Garedu Red Bed deposition clearly indicates the inception of a prominent compressive tectonic event being the strongest at the eastern margin of the northern Tabas Block (northern Shotori Mountains). The same tectonic event (i.e., the Late Cimmerian Tectonic Event, LCTE) is expressed by the simultaneous drowning of the Esfandiar Platform in the southern Shotori Mountains (Fürsich et al. 2003a; Schairer et al. 2003), thus indicating concurrent distension along the same fault (i.e., the Nayband Fault). In addition, the onset of deposition of the Magu Gypsum Formation including the basal Nar Conglomerate in the western part of the northern Tabas Block, unconformably overlying the shelf lagoonal strata of the Kamar-e-Mehdi Formation (Wilmsen et al. 2010; cf. Figure 1c), is associated with it. A meaningful geodynamic model must consequently encompass all different regional tectono-stratigraphic signatures.

Mattei et al. (2014) proposed a rapid plate shift of Eurasia, including the Iran Plate, to lower palaeo-latitudes from ca. 160-145 Ma, also derived from palaeomagnetic studies of the GRBF (note, however, that palaeomagnetic data for counterclockwise rotation derived from that unit postdate its deposition). They explain the succession of sedimentary facies in Iran during the Jurassic from coal-bearing siliciclastics (Lower to lower Middle Jurassic Ab-e-Haji Subgroup of the Shemshak Group) via carbonate platform deposits of the Esfandiar Subgroup to red beds and evaporates of the Garedu Subgroup by a rapid southward plate shift across 


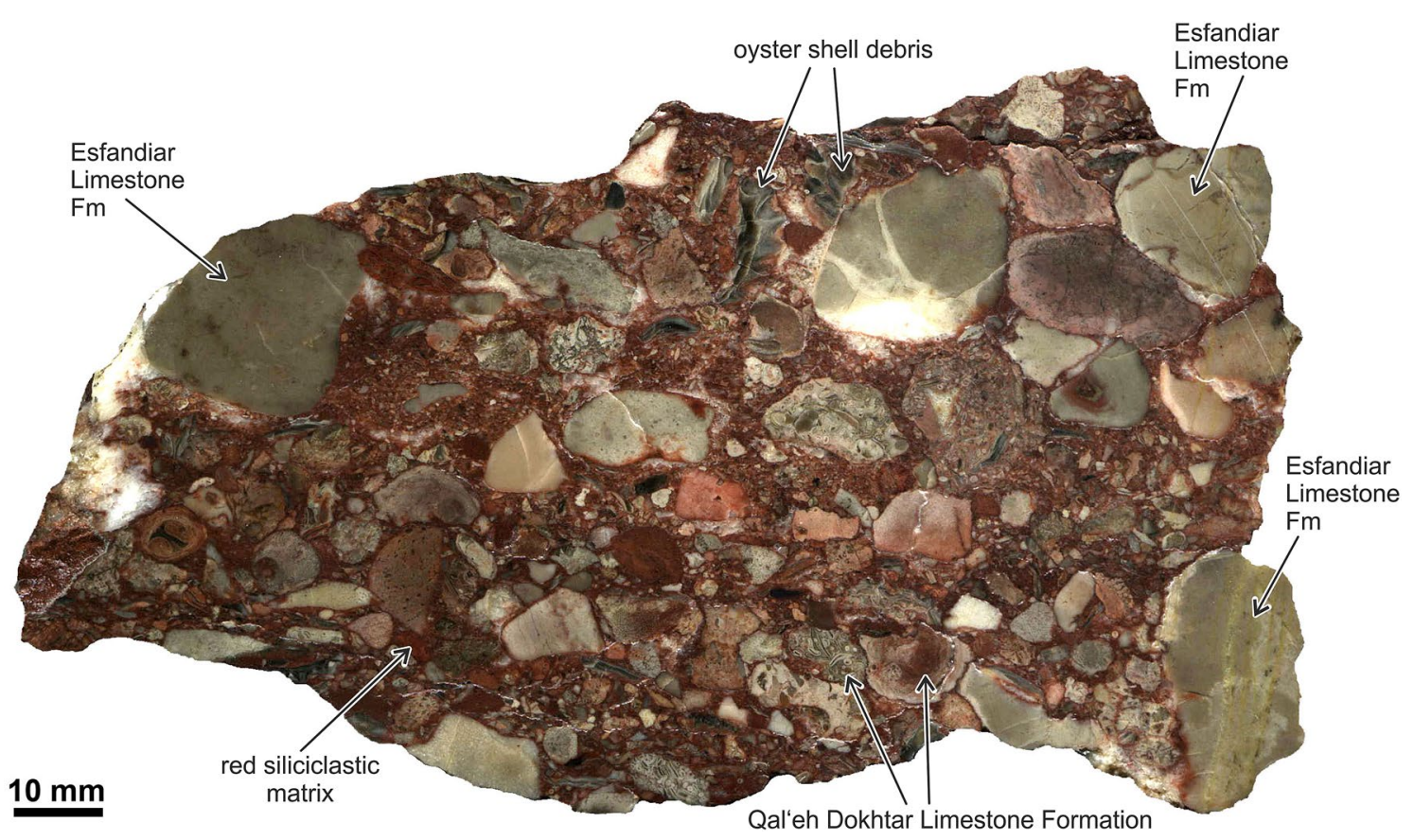

Fig. 5 Polished slab of a limestone conglomerate of facies type FT-1b from the lowermost Garedu Red Bed Formation in the section north of Honu (sample 020213-11)

the humid temperate to arid (sub-)tropical climate belts. Furthermore, Cifelli et al. (2013) suggested, based on magnetic susceptibility and structural analyses of the GRBF, that the tectonic regime at the Nayband Fault between the Lut and Tabas blocks changed from normal faulting during the Jurassic to right-transpressional sometime during the Early Cretaceous to Palaeocene. Counterclockwise vertical axis tectonic rotations of the CEIM occurred, according to Mattei et al. (2015), during the Early Cretaceous and after the Middle-Late Miocene; the trigger for the first rotation phase may have been the northward propagation of the Sistan rifting/spreading axis or the subsequent late Early to Late Cretaceous eastward subduction below the Afghan Block and closure of the Sistan Ocean. New palaeomagnetic data of Mattei et al. (2015, fig. 7) support an E-W-orientation of the blocks of the CEIM during the Jurassic with the Lut Block facing the Neotethys, as already proposed by Wilmsen et al. (2009a, 2010) based on facies reconstructions of the Esfandiar Subgroup carbonate system. The above mentioned studies all present important results but, taken alone, fail to explain the complex facies pattern, stratigraphic relationships, and timing of tectonic events within the upper Middle to Upper Jurassic Esfandiar and Garedu subgroups of the northern Tabas Block in full detail. However, all data can be merged into a comprehensive geodynamic model integrating almost all tectonic, stratigraphic, sedimentological, and palaeomagnetic aspects (Fig. 11).
Fig. 6 Microfacies images of the Garedu Red Bed Formation (GRBF, $w=$ horizontal width of photomicrograph). a limestone conglomerate of facies type FT-1a, type section of the GRBF (sample 000307$8, w=15 \mathrm{~mm}$ ); note rounded and angular limestone lithoclasts derived from the Esfandiar (E) and Qal'eh Dokhtar (Q) Limestone formations. b Limestone conglomerate of facies type FT-1a, Kuh-eTalkhori (sample 010225-12/2, w=25 mm); note reddish siltstone lithoclast (si) in lower part. c Limestone conglomerate of facies type FT-1a, type section of the Nar Conglomerate Member of the Magu Gypsum Formation in the Echellon area (sample 000310-8 from the matrix of the conglomerate bed, $w=20 \mathrm{~mm}$ ). d Limestone conglomerate of facies type FT-1b, section north of Honu (sample 020213-11, $w=30 \mathrm{~mm})$. e Limestone conglomerate of facies type FT-1b, OzbakKuh (sample 000229-1, w=15 mm); note cross- and longitudinal sections of cidaroid echinoid spines (e). f Fine-grained sandstone of facies type FT-4, Ozbak-Kuh (sample 000229-5, $w=15 \mathrm{~mm}$ ); note poor textural maturity of light quartz grains and numerous grey carbonate grains. g Litho-/bioclastic rudstones of facies type FT-6, Ozbak-Kuh (sample 000229-4, w=15 mm); note coral (c), oyster (oy), echinoderm (e) and chaetetid (ch) fragments as well as small limestone lithoclasts (li). h Microbialite of facies type FT-7 covering a large lithoclasts (li) of the Esfandiar Limestone Formation, upper part of a conglomerate bed of FT-1 in the section north of Honu (sample 020213-13, w=20 mm)

It is important to note that all facies reconstructions for the Early to early Late Jurassic indicate normal faulting at the block-bounding faults of the CEIM (Fürsich et al. 2003a, b; Wilmsen et al. 2009a, 2010; Salehi et al. 2014, 2018). The blocks were approximately E-W-oriented, the Lut Block faced the Neotethys with its subduction zone, and the normal faulting is compatible with an extensional 

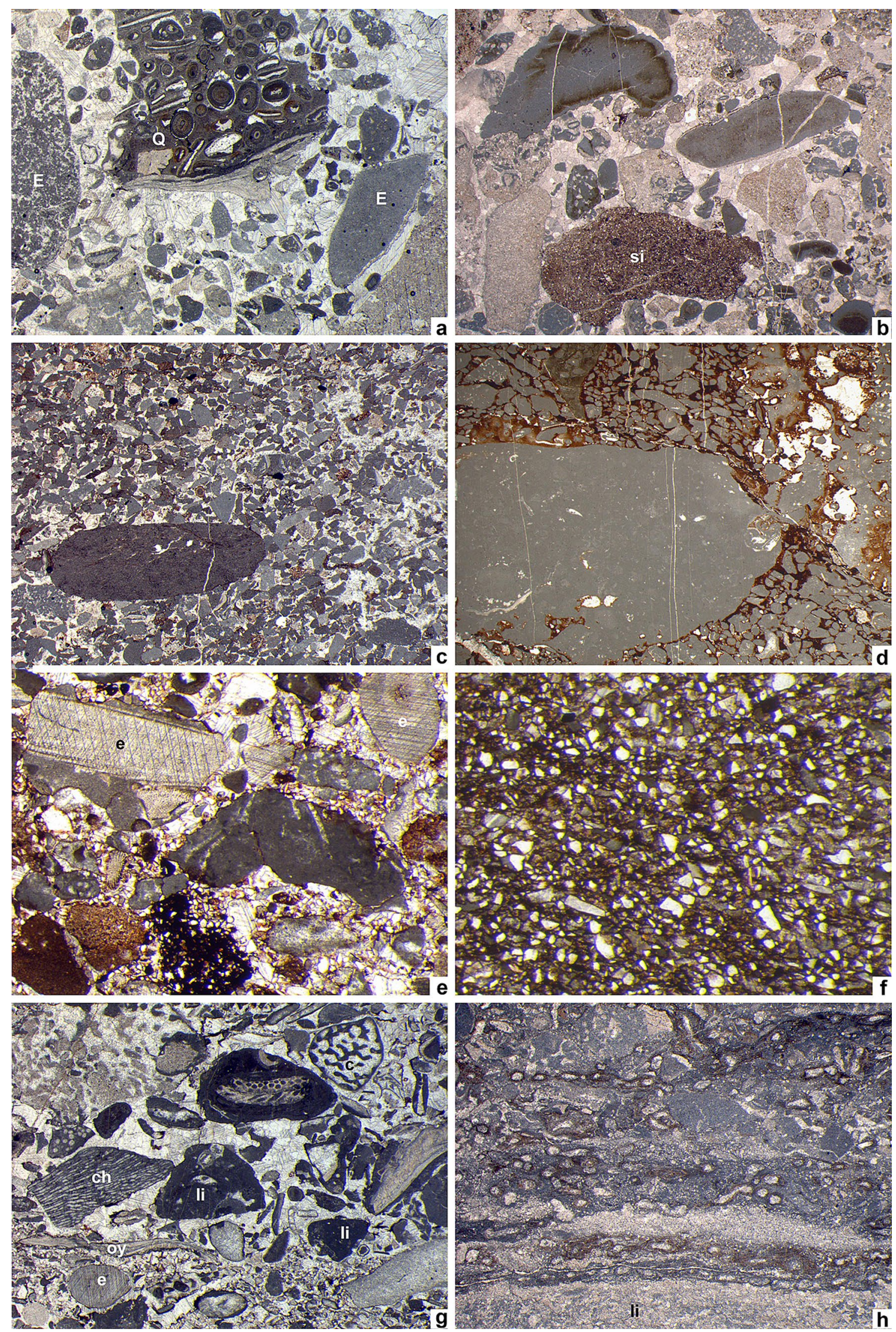

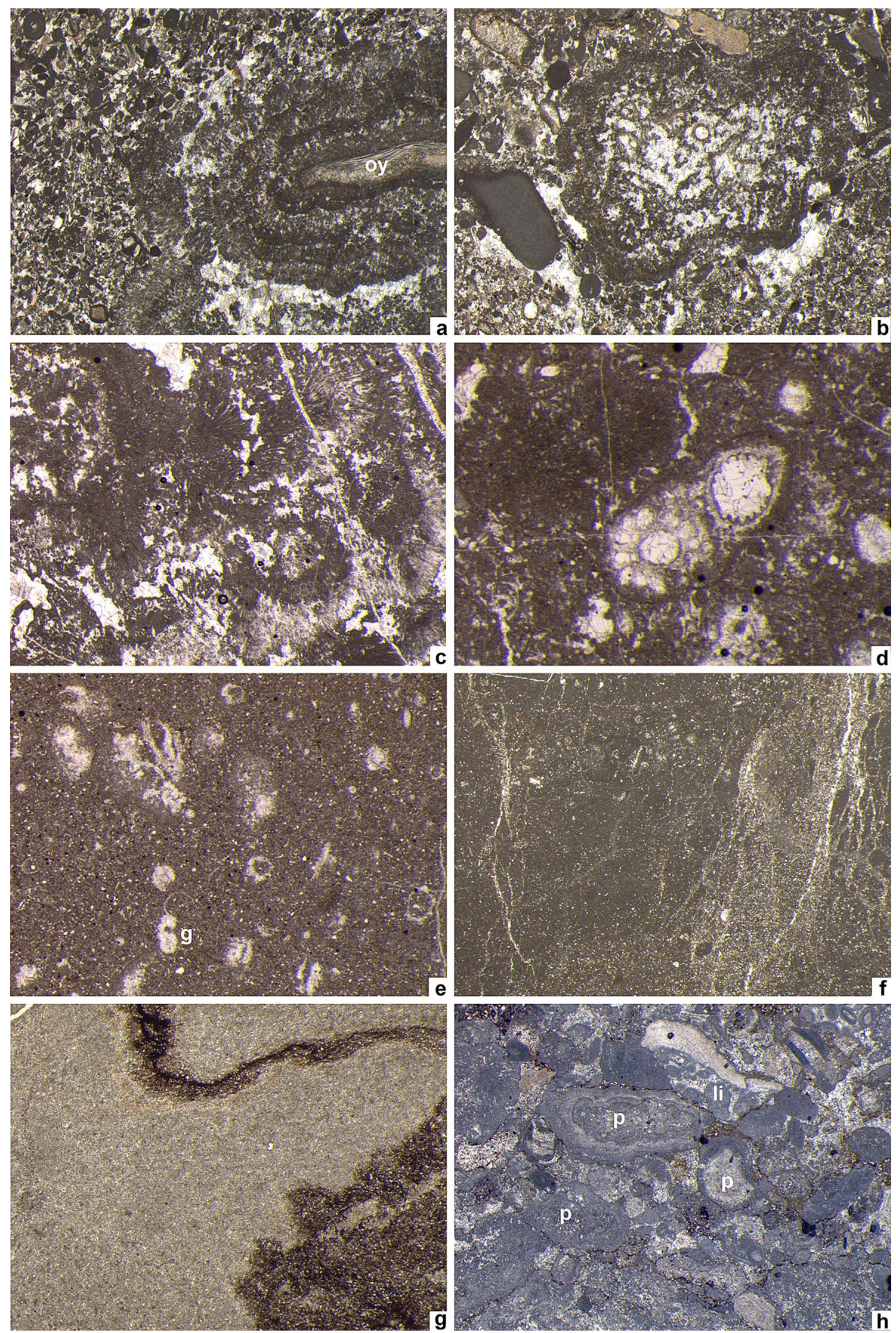
4Fig. 7 Microfacies images of the Garedu Red Bed Formation (GRBF, $w=$ horizontal width of photomicrograph). a, b Oncoid floatstone of facies type FT-8 (sample 000229-7 from Ozbak-Kuh, $w=15 \mathrm{~mm}$ ); oncoids are formed by weakly calcified oscillatoriacean cyanobacteria (note oyster shell fragment-oy-as nucleus in A). c, d Algal tufa (facies type FT-9) with bind- to bafflestone fabric formed by oscillatoriacean cyanobacteria and characean algae; note characean thallus and attached gyrogonite in situ in D (sample 000307-5 from the type section of the GRBF, wC $=6 \mathrm{~mm}, w \mathrm{D}=3 \mathrm{~mm}$ ). e, Characean wackestone of facies type FT-10 (sample 000307-4 from the type section of the GRBF, $w=6 \mathrm{~mm}$ ); note small gastropod (g) and the fine silt component. f, $\mathbf{g}$ Silty caliche mudstones of facies type FT-11 with pedogenic-rhizolitic fabrics (F, sample 000229-8 from Ozbak-Kuh and G, sample 020213-15 from north of Honu; $w F=20 \mathrm{~mm}, \mathrm{wG}=10 \mathrm{~mm}$ ). h Pisolitic (p) rudstone with lithoclasts (li) of facies type FT-12 (sample 010225-12/1 from Kuh-e-Talkhori, $w=15 \mathrm{~mm}$ ) regime in a back-arc setting (Fig. 11a). This situation has been clearly documented by Fürsich et al. (2003a, b) and Wilmsen et al. (2010) based on the facies architecture, thickness changes and spatial distribution of Callovian to Oxfordian formations on the northern Tabas Block and the northwestern Lut Block (see also Salehi et al. 2014, 2018 for the Lower Jurassic Ab-Haji Formation). However, the tectonic regime obviously changed abruptly across the Oxfordian-Kimmeridgian boundary, because the facies patterns and stratigraphic relationships outlined herein indicate a shift along the Nayband Fault from compressional in the north to extensional in the south, best explained by the onset of a (right-)transpressional tectonic regime and the initiation of

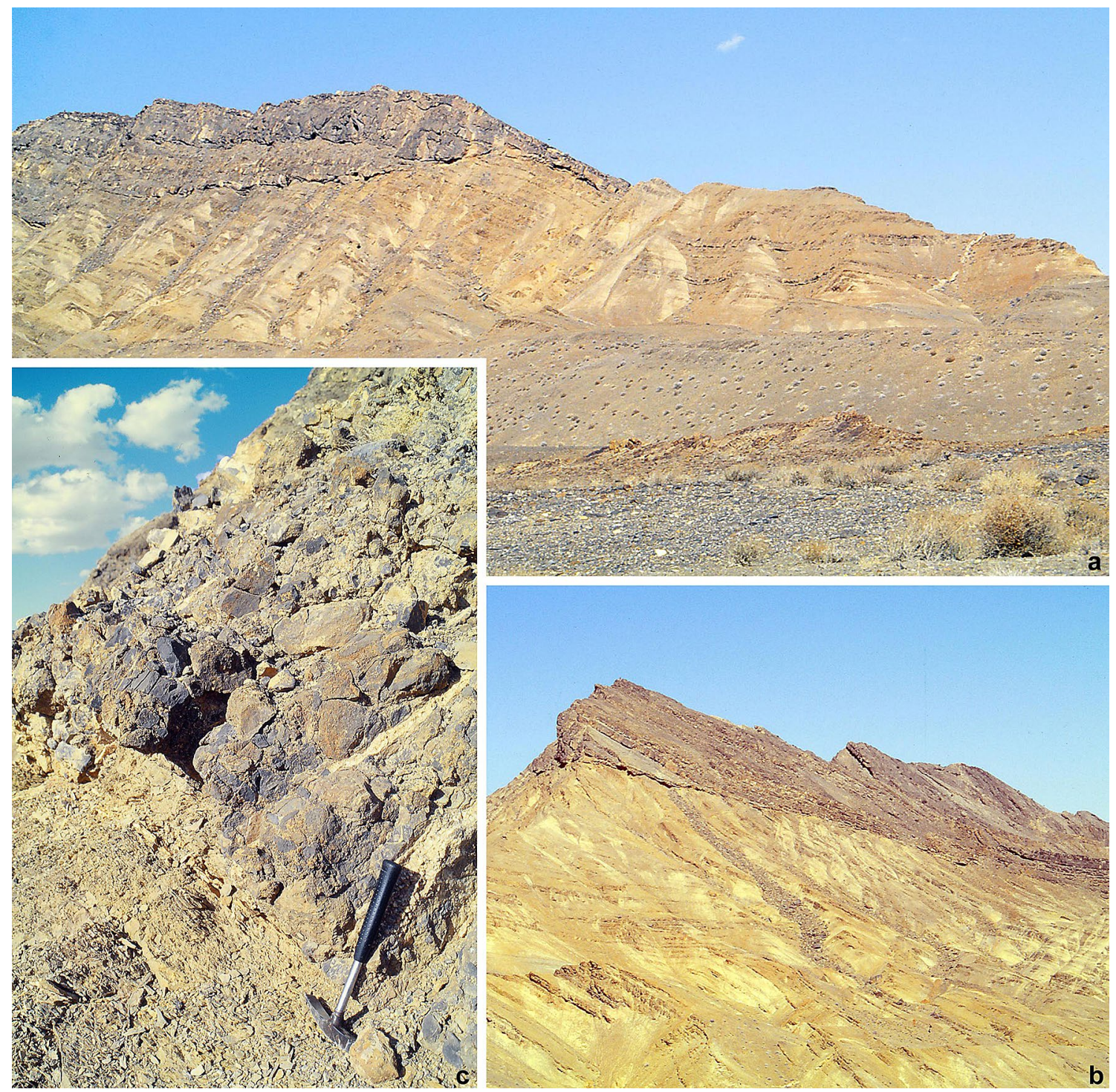

Fig. 8 Field aspects of the Esfak section (upper Qal'eh Dokhtar Limestone Formation, Sect. 7 in Fig. 1b). a Panoramic view from the southeast showing the massive, decametre-scale incision of dark grey limestone conglomerates into basinal calcareous mudstones of the upper Qal'eh Dokhtar Limestone Formation. b View from the east onto the Esfak conglomerate unit cutting into the upper Qal'eh Dokhtar Limestone Formation. c Basal contact of the Esfak conglomerates resting erosionally on fissile marly mudstones of the upper Qal'eh Dokhtar Limestone Formation 
Fig. 9 Upper Qal'eh Dokhtar Limestone and lowermost Korond formations in the Esfak section (section no. 7 in Fig. 1).

The interval of the Esfak conglomerate $(0-70 \mathrm{~m})$ is indicated

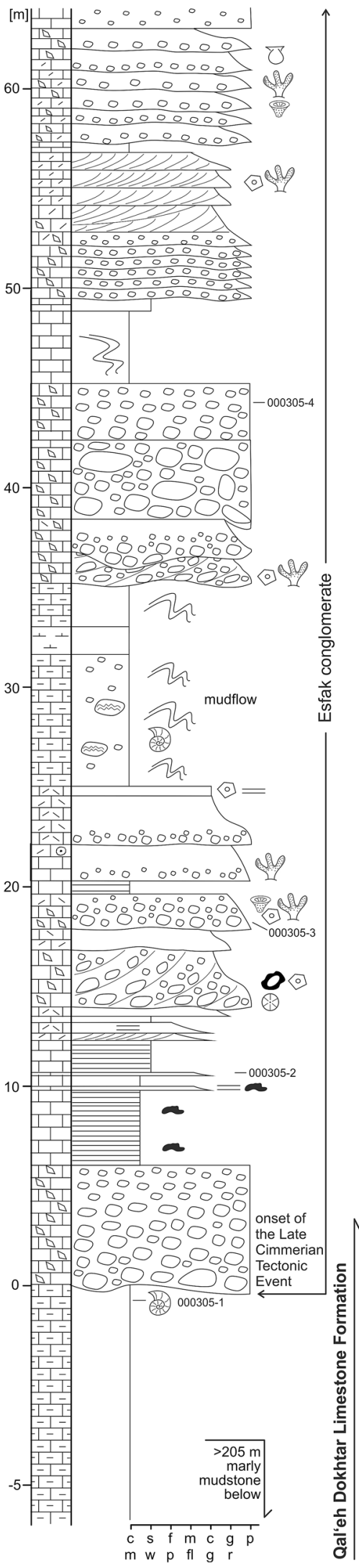

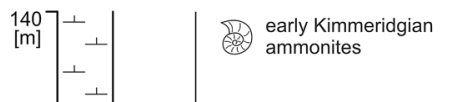

130

$120-$

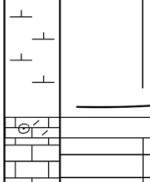

Korond Formation

$110-$

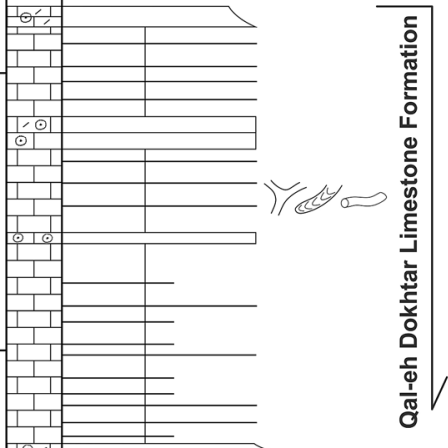

100

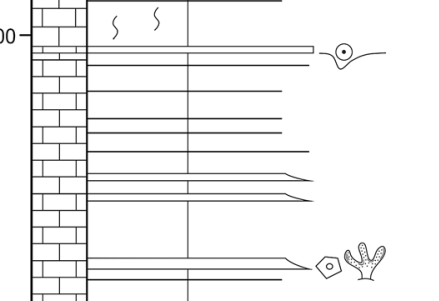

90

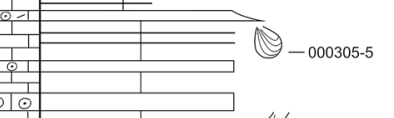

$\odot \odot$

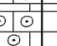

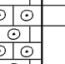

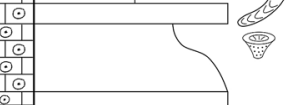

ح gutter cast
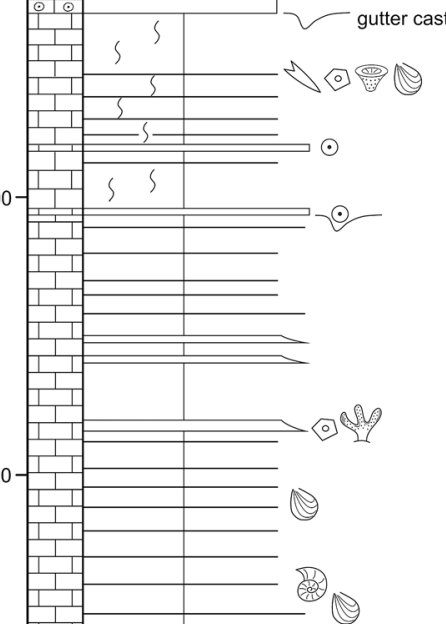

80

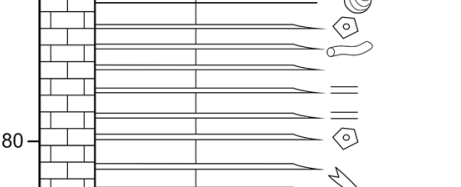


significant counterclockwise rotations of the CEIM already during the mid-Late Jurassic. Nur et al. (1989) showed that block rotations create heterogeneities along with active fault systems and that one of the most important aspects in (sub-) parallel fault sets in domains (such as in the CEIM) is the rotation of the blocks between the faults when they slip and, consequently, the rotation of the faults themselves; simple geometric and kinematic considerations show that block and fault rotations associated with fault-slip movements imply that sets with right-lateral slip undergo counterclockwise rotation. Wallace et al. (2008) documented that significant modern-day tectonic block rotations on Earth occur at convergent plate margins where a buoyant indentor enters a subduction zone and that the rate of microplate rotation depends on the velocity of the incoming indentor. The velocity of any potential buoyant indentor (such as a larger seamount or small terrane) impacting the subduction zone south of the Lut Block should have been fairly high, inducing significant rotating forces associated with fault-slip movements. Starting with the Kimmeridgian (ca. $155 \mathrm{Ma}$ according to the new Jurassic time scale of Hesselbo et al. 2020), this buoyant indentor would have pushed the southeastern margin of the CEIM into the Turan Plate, effectively transferring much of the plate boundary shortening to the upper plate and inducing counterclockwise rotation (Fig. 11b, c; see also Walker and Jackson 2004, fig. 16). Rotation of the CEIM occurred within bracketing transcurrent faults (today the Great Kavir/Doruneh Fault and the East-Lut Fault that obtained their current shapes from this vertical-axis block rotation; Walker and Jackson 2004; Walpersdorf et al. 2014), and continued counterclockwise rotation during the Early Cretaceous finally opened narrow oceanic basins around the rotating microplate along these deep-seated major faults (see also Pirnia et al. 2020 for a new Cretaceous reconstruction). The intra-CEIM block boundaries accommodated the rotation by right-lateral strike-slip, transpressional in the eastern (today northern) segments and transtensional in the western (today southern) segments of the block-bounding faults (Fig. 11c; cf. Wallace et al. 2008, fig. 3). Walpersdorf et al. (2014) showed that right-lateral slip at the East Lut, Nayband, and Kalmard faults still occurs today with rates of ca. $4-6 \mathrm{~mm} / \mathrm{year}$ and identified large strains at the (today northern) tips of the rotating faults that explain the widespread secondary faulting and pronounced seismic activity in those areas. They also document extensional and compressional deformation across the faults as the rotating

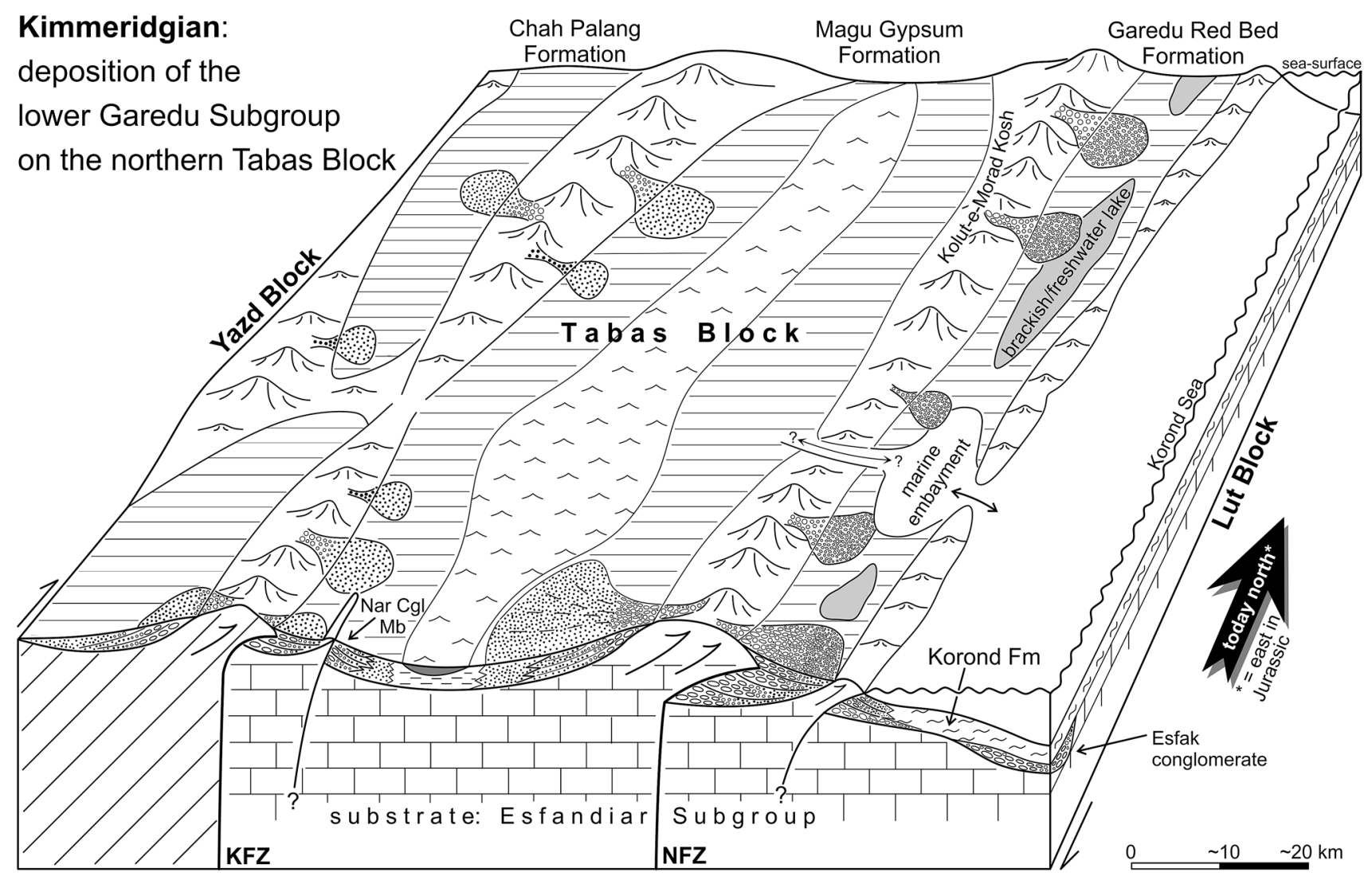

Fig. 10 Depositional and palaeogeographic model of the northern part of the CEIM north of Tabas (see Fig. 1b) during the Kimmeridgian (deposition of the lower Garedu Subgroup). KFZ Kalmard Fault zone; NFZ Nayband Fault zone; Nar Cgl Mb Nar Conglomerate Member of the Magu Gypsum Formation. See text for further explanation 
blocks indent or separate from each other. Such signatures are typical for transrotational basins (Ingersoll 1988; Nilsen and Sylvester 1995) and this scenario elegantly explains the hitherto conflicting observations along the Nayband Fault of shortening in the northern Shotori Mountains (GRBF) and contemporaneous extension in the southern Shotori Mountains (drowning of the Esfandiar Platform: Fürsich et al. 2003a; Fig. 11c). The Esfak conglomerate in the uppermost Qal'eh Dokhtar Limestone Formation is correspondingly regarded as a marine basinal signature of the tectonic uplift in the northern Shotori Mountains (Fig. 10). After the initial major uplift indicated by the repeated pulses of conglomerate deposition (Fig. 9), the uppermost part of the Qal'eh Dokhtar Formation with its intercalated allodapic limestones and mudstones indicate a localized persistence of shallow marine carbonate deposition that is fading-away up-section into the Korond Formation.

We can only speculate about the nature of the buoyant indentor. If not fully destroyed by subsequent subduction processes, its remnants have to be tracked at the present northeastern margin of the Lut Block (Dasht-e-Bayaz), an area that is strongly tectonized, metamorphosed and overprinted by the latest Cretaceous to Palaeogene closure of the Sistan and Sabzevar oceans (e.g., Omrani et al. 2013; Delavari et al. 2014). However, Late Jurassic terrane collision with the southern Eurasian margin is known from the Lhasa and Qiangtang terranes farther east (Li et al. 2019). Also the Central Afghan Block mosaic with Gondwanaderived terranes (including the Helmand Block) accreted during the Late Jurassic-Early Cretaceous (Siehl 2015). In the west, Azizi and Asahara (2013) suggest a collision of an island arc with the western part of the Sanandaj-Sirjan Zone during the Late Jurassic to Early Cretaceous and Lechmann et al. (2018) propose an extensional event for northwestern Iran based on mantle-derived magmas intruding a thinned lithosphere. This event resulted in the formation of oceanic lithosphere between the Sanandaj-Sirjan Zone and Central Iran (Khoy ophiolite).

\section{Palaeogeography}

In a regional palaeogeographic context, the Kuh-e-Birg conglomerate is a lithologically very similar and stratigraphically equivalent conglomerate unconformably resting on the Qal'eh-Dokhtar and Esfandiar Limestone formations at Kuh-e-Birg, $80 \mathrm{~km}$ east of the Shotori Mountains on the Lut Block (Fig. 1b). It indicates a much wider distribution of the Garedu Red Beds, at least in certain places. Also the coarse-grained conglomerates and red beds of the Chah Palang and Noqreh Formations of the Khur area (northern Yazd Block, Figs. 10, 11) indicate a major Late Jurassic to the earliest Cretaceous tectonic event including the formation of a considerable Late Cimmerian palaeo-relief that has been levelled during the Early Cretaceous (Wilmsen et al. 2013, 2015, 2020). Furthermore, the red beds of the Shurijeh Formation of northeastern Iran are a sedimentologically (alluvial fan and fluvial deposits with occasional marine ingressions) and stratigraphically (latest Jurassic to earliest Cretaceous) comparable unit, likewise terminating a large-scale carbonate platform system and reflecting similar arid to semi-arid climatic conditions (Moussavi-Harami and Brenner 1990; Moussavi-Harami et al. 2009; Hosseinyar et al. 2019). The effects of the latest Jurassic to the earliest Cretaceous tectonic event are also seen in the northerly adjacent Amu-Darya Basin (Fig. 11a) by the increasing restriction of the Middle-Late Jurassic Gissar carbonate platform which reached its peak during the Tithonian (Carmeille et al. 2018). These observations show that not only the CEIM has been affected by the Late Cimmerian tectonic instability, and we speculate that tectonic movements along the transcurrent faults bracketing the CEIM are responsible for transferring the tectono-stratigraphic signatures of the Late Cimmerian Tectonic Event to northeast Iran (Fig. 11a). However, similar uppermost Jurassic to lowermost Cretaceous coarse-grained red siliciclastics are also known from a continental retro-arc basin adjacent to uplifted basement in the Sanandaj-Sirjan Zone near Esfahan (NW Iran; Salehi and Tadayon 2020) and, in an inter-regional comparison, the Late Cimmerian tectonic unconformity is widespread in the entire Middle East (e.g., Kendall et al. 2014, fig. 2). Thus, even if our geodynamic model successfully explains tectonic rotations, fault motions and facies distribution in the northern part of the CEIM during the Late Jurassic, a more general explanation for the basic cause of the Late Cimmerian tectonics is still lacking.

\section{Conclusions}

The Garedu Red Bed Formation (GRBF) of the northern Tabas Block (part of the Central-East Iranian Microcontinent, CEIM) represents a lithologically variable, up to 500-m-thick unit combining a complex suite of predominantly continental facies types. It is distributed in the northern Shotori Mountains, overlies marine limestones of the Esfandiar Subgroup carbonate system (Callovian-Oxfordian) with both, gradual and unconformable basal contacts, and is assigned to the Kimmeridgian-Tithonian, but may well range into the lowermost Cretaceous. The lower part of the formation consists of coarsely bedded and poorly sorted pebble- to boulder-conglomerates/breccias composed of limestone clasts within a sandy matrix and/or calcareous cement. The limestone conglomerates are interbedded with calcareous bioclastic sandstones and litho-/bioclastic 
Fig. 11 Palaeogeographic reconstruction (a) and geodynamic model (b, c) for the Garedu Red Bed Formation (b and $\mathbf{c}$ not to scale). a Late Callovian-early Oxfordian palaeogeography (map segment strongly modified and expanded from Thierry 2000 using data of Wilmsen et al. 2010, Mattei et al. 2015, Siehl 2015 and Barrier et al. 2018); the Lut, Tabas and Yazd blocks are shown in pre-rotational position ( $A D B$ Amu-Darya Basin, $A T B$ Afghan-Tajik Basin, $C A$ central Afghanistan, CEIM Central-East Iranian Microcontinent, $F B$ Farah Basin, $G C B$ Greater Caucasus Basin, $H B$ Helmand Block; $K D$ Koppeh Dagh, NWI Northwest Iran, SCB South Caspian Basin, SiB Sistan Basin, SSZ Sanandaj-Sirjan Zone). b Schematic representation of the three blocks of the CEIM shown in pre-rotational position (Callovian-Oxfordian); a buoyant indentor (black circle) is shown shortly before collision with the south-eastern margin of the CEIM. c Starting with the Kimmeridgian, the buoyant indentor induced counterclockwise rotation of the CEIM, which occurred within bracketing transcurrent faults (see text for further explanation; GRBF Garedu Red Bed Formation, MGF Magu Gypsum Formation, NSM northern Shotori Mountains, SSM southern Shotori Mountains). The shown amount of inferred counterclockwise vertical-axis rotation of the CEIM is exaggerated in order to illustrate the kinematics at the blockbounding faults more clearly

rudstones as well as lacustrine carbonates (algal tufas, characean wackestones, oncolitic floatstones and microbialites). Up-section, conglomerate intercalations become rarer and thinner, and sharp-based, partly pebbly sandstones and red siltstones and fine-grained sandstones of braided river origin (gravel bars, channel fills, floodplain fines) predominate. Red colours and pedogenic features such as calcretes suggest arid to semi-arid climatic conditions. The asymmetric facies distribution and imbrication of clasts indicate a principal sediment transport from west to east. Lateral interfingering of the predominantly continental Garedu Red Beds with the greenish sandy marls of the marine Korond Formation took place at the eastern margin of the Tabas Block, onto the Lut Block. Towards the west, the GRBF grades into the playa deposits of the Magu Gypsum Formation.

The CEIM consists, from $\mathrm{W}$ to E, of the Yazd, Tabas, and Lut blocks, the long axes of which are nowadays N-Soriented. In the Early and Middle Jurassic, the blocks were approximately E-W-oriented, the Lut Block faced the Neotethys subduction zone, and the block boundaries were characterized by normal faulting, compatible with an extensional regime in a back-arc setting. The onset of Garedu Red Bed deposition clearly indicates a major geodynamic change with the onset of compressive tectonics of the Late Cimmerian Tectonic Event being strongest at the eastern margin of the northern Tabas Block. Especially in the lower part of the GRBF, considerable lateral variation in thickness and facies indicate fault-controlled deposition in a closely spaced array of uplifted and downthrown blocks, typically occurring in strike-slip settings. When traced southwards, the same tectonic event is expressed by the simultaneous drowning of the Esfandiar carbonate platform in the southern Shotori Mountains, indicating a shift from compression to extension along the boundary between the Tabas and Lut blocks
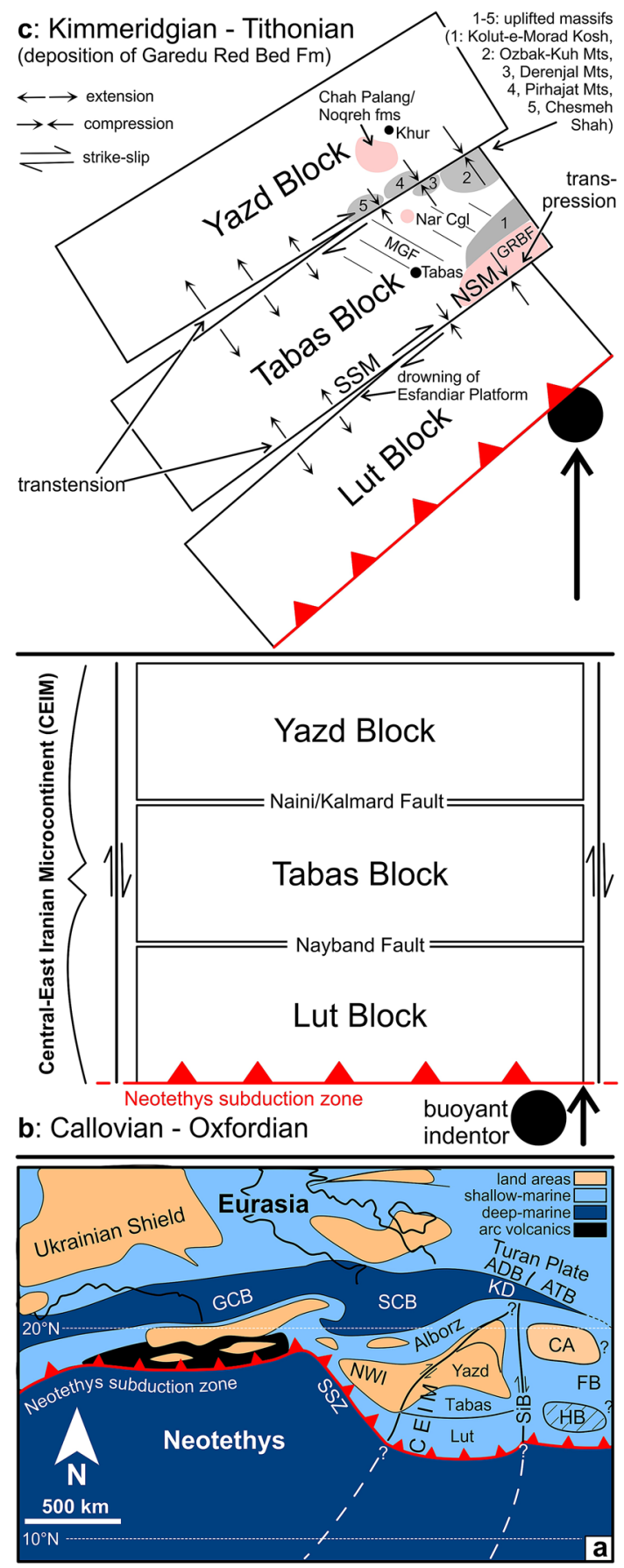

(i.e., the Nayband Fault). The complex Upper Jurassic facies distribution and the spatio-temporal changes in the tectonic regime along the block-bounding faults are explained by the onset of counterclockwise vertical-axis block rotation of the CEIM in the Kimmeridgian in response to the localized impact of a buoyant indentor, such as a large seamount or terrane, into the Neotethys subduction zone at the eastern (today north-eastern) margin of the Lut Block. The block boundaries accommodated the rotation by right-lateral strike-slip movements, transpressional in the eastern (today 
northern) segments and transtensional in the western (today southern) segments of the block-bounding faults. Rotation occurred within bracketing transcurrent faults (the Great Kavir/Doruneh and East-Lut or Sistan faults) and continued into the Early Cretaceous, ultimately leading to the opening of the narrow oceanic basins encircling the CEIM (Sistan, Sabzevar, and Nain-Baft oceans).

Palaeogeographically, the GRBF is part of a number of conglomeratic, red-siliciclastic formations that are not only present in different areas of the CEIM, but also occur along the Sanandaj-Sirjan Zone in northwest Iran and in northern/ northeastern Iran (Alborz and Koppeh Dagh mountains), indicating widespread tectonic instability, uplift, and erosion under arid to semiarid climatic conditions across the Jurassic-Cretaceous boundary. Furthermore, the Late Cimmerian tectonic unconformity is widespread in the entire Middle East. Thus, even if our geodynamic model successfully explains Late Jurassic tectonic rotations, fault motions, and facies distribution in the northern part of the CEIM, a more general explanation for the basic cause of the Late Cimmerian tectonics is still lacking.

Acknowledgements Constructive reviews by Marie-Francoise Brunet (Paris) and Massimo Mattei (Rome) are gratefully acknowledged. We are also indebted to the Geological Survey of Iran for continuous logistic support. Financial funding was provided by National Geographic project (grant 5888-97). Felix Schlagintweit (München) is thanked for microfossil identification.

Funding Open Access funding enabled and organized by Projekt DEAL.

Open Access This article is licensed under a Creative Commons Attribution 4.0 International License, which permits use, sharing, adaptation, distribution and reproduction in any medium or format, as long as you give appropriate credit to the original author(s) and the source, provide a link to the Creative Commons licence, and indicate if changes were made. The images or other third party material in this article are included in the article's Creative Commons licence, unless indicated otherwise in a credit line to the material. If material is not included in the article's Creative Commons licence and your intended use is not permitted by statutory regulation or exceeds the permitted use, you will need to obtain permission directly from the copyright holder. To view a copy of this licence, visit http://creativecommons.org/licenses/by/4.0/.

\section{References}

Aghanabati SA (1977) Etude géologique de la région de Kalmard (W. Tabas). Stratigraphie et tectonique. Geol Surv Iran Rep 35:1-230 Aghanabati A (1998) Jurassic stratigraphy of Iran, 1-2. Geological Survey of Iran, Tehran, p 746

Alavi M, Vaziri H, Seyed-Emami K, Lasemi Y (1997) The Triassic and associated rocks of the Nakhlak and Aghdarband areas in central and northeastern Iran as remnants of the southern Turan active continental margin. Geol Soc Am Bull 109:1563-1575
Azizi H, Asahara Y (2013) Juvenile granite in the Sanandaj-Sirjan Zone, NW Iran: Late Jurassic-Early Cretaceous arc-continent collision. Intern Geol Rev 55:1523-1540

Babazadeh SA, De Wever P (2004) Radiolarian Cretaceous age of Soulabest radiolarites in ophiolite suite of eastern Iran. Bull Soc Géol France 175:121-129

Bagi H, Tasli K (2007) Paleoenvironmental analysis and biostratigraphy of the Upper Jurassic Esfandiar Formation (East-Central Iran). Neues Jahrb Geol Paläont 243:101-111

Barrier E, Vrielynck B (2008) Map 3: Callovian (167.7-161.2 Ma). In: Barrier E, Vrielynck B (eds) Palaeotectonic maps of the Middle East-tectono-sedimentary-palinsspastic maps from the Late Norian to Pliocene. Commission for the Geological Map of the World (CGMW/CCGM), Paris

Barrier E, Vrielynck B, Brouillet JF, Brunet MF (2018) Map 6: late Tithonian (149-145.0 Ma). In: Barrier E, Vrielynck B, Brouillet JF, Brunet MF (eds) Paleotectonic reconstruction of the central Tethyan Realm. Tectonono-sedimentary-palinspastic maps from Late Permian to Pliocene. Commission for the Geological Map of the World (CCGM/CGMW), Paris

Bassoullet JP (1997) Les grands foraminifères. In: Cariou E, Hantzpergue $\mathrm{P}$ (coord) Biostratigraphie du Jurassique ouest-Européen et Méditerranéen, vol 17. Bulletin des Centres Recherche Exploration-Production Elf-Aquitaine, Mémoire, pp 294-304

Berberian M, King GCP (1981) Towards a palaeogeography and tectonic evolution of Iran. Can J Earth Sci 18:210-265

Besse J, Torcq F, Gallet Y, Ricou LE, Krystyn L, Saidi A (1998) Late Permian to Late Triassic palaeomagnetic data from Iran: constraints on the migration of the Iranian block through the Tethyan Ocean and initial destruction of Pangaea. Geophys J Intern 135:77-92

Carmeille M, Bourillot R, Brunet M-F, Pellenard P, Fürsich FT, Schnyder J, Barrier E, Blanpied C, Sidorova I (2018) Architecture and sedimentary evolution of the southwestern Gissar carbonate platform (Uzbekistan) during the Middle-Late Jurassic. Mar Petrol Geol 97:437-465

Cifelli F, Mattei M, Rashid H, Ghalamghash J (2013) Right-lateral transpressional tectonics along the boundary between Lut and Tabas blocks (Central Iran). Geophys J Intern 193:1153-1165

Delavari M, Amini S, Schmitt AK, McKeegan KD, Harrison MT (2014) U-Pb geochronology and geochemistry of Bibi-Maryam pluton, eastern Iran: Implication for the late stage of the tectonic evolution of the Sistan Ocean. Lithos 200-201:197-211

Dunham RJ (1962) Classification of carbonate rocks according to depositional texture. In: Ham WE (ed) Classification of carbonate rocks, vol 1. The American Assocation of Petroleum Geologists, Memoir, pp 108-121

Embry AF, Klovan JE (1971) A late Devonian reef tract on northeastern Banks Island, Northwest Territories. Bull Can Petrol Geol 19:730-781

Fürsich FT, Wilmsen M, Seyed-Emami K, Schairer G, Majidifard MR (2003a) Platform/basin transect of a large-scale Middle-Late Jurassic carbonate platform system (Shotori Mountains, Tabas area, east-central Iran). Facies 48:171-198

Fürsich FT, Wilmsen M, Seyed-Emami K, Majidifard MR (2003b) Evidence of synsedimentary tectonics in the northern Tabas Block, east-central Iran: The Callovian (Middle Jurassic) Sikhor Formation. Facies 48:151-170

Gallois A, Bosence D, Burgess PM (2018) Brackish to hypersaline facies in lacustrine carbonates: Purbeck Limestone Group, Upper Jurassic-Lower Cretaceous Wessex Basin Dorset UK. Facies 64:12

Galloway WE, Hobday DK (1996) Alluvial Fans. In: Galloway WE, Hobday DK (eds) Terrigenous clastic depositional systems. Springer, Berlin, pp 29-59 
Gierlowski-Kordesch EH (2010) Lacustrine carbonates. Dev Sediment 61:1-101

Goldring R (1999) Field palaeontology, 2nd edn. Longman, Singapore, p 191

Hesselbo SP, Ogg JG, Ruhl M (2020) The Jurassic Period. In: Gradstein FM, Ogg JG, Schmitz MD, Ogg GM (eds) Geologic time scale 2020, vol 2. Elsevier, Amsterdam, pp 955-1021

Hosseinyar G, Moussavi-Harami R, Abdollahie Fard I, Mahboubi A, Noemani Rad R, Ebrahimi M-H (2019) Facies analyses and depositional setting of the Lower Cretaceous Shurijeh-Shatlyk formations in the Kopeh Dagh-Amu Darya Basin (Iran and Turkmenistan). Geol J 54:1715-1729

Huckriede R, Kürsten M, Venzlaff H (1962) Zur Geologie des Gebietes zwischen Kerman und Sagand (Iran). Geol Jb Beih 51:1-197

Ingersoll RV (1988) Tectonics of sedimentary basins. Geol Soc Am Bull 100:1704-1719

Kazemi Z, Ghasemi H, Tilhac R, Griffin W, Shafaii Moghadam H, O'Reilly S, Mousivand F (2019) Late Cretaceous subductionrelated magmatism on the southern edge of Sabzevar basin, NE Iran. J Geol Soc 176:530-552

Kendall CCG, Alsharan AS, Marlow L (2014) Stratigraphy and depositional systems of the southern Tethyan region. In: Marlow L, Kendall CCG, Yose LA (eds) Petroleum systems of the Tethyan region, vol 106. AAPG Memoir, pp 29-57

Kluyver HM, Griffis R, Tirrul R, Chance PN, Meixner HM (1983a) Explanatory text of the Lakar Kuh quadrangle map 1:250.000. Geol Surv Iran Quadr Map 19:1-175

Kluyver HM, Tirrul R, Chance PN, Johns GW, Meixner HM (1983b) Explanatory text of the Naybandan Quadrangle map 1:250.000. Geol Surv Iran Geol Quadr J8:1-143

Lechmann A, Burg J-P, Ulmer P, Mohammadi A, Guillong M, Faridi M (2018) From Jurassic rifting to Cretaceous subduction in NW Iranian Azerbaijan: geochronological and geochemical signals from granitoids. Contrib Mineral Petrol 173:102

Li L, Garzione CN, Fan M, Li X, Li X (2019) Jurassic sedimentation in the south-central Qiangtang terrane reveals successive terrane collisions in central Tibet. Geosphere 15:433-449

Lotfi M (1995) Geological quadrangle map of Iran, series 1:100000, map sheet 7656, Sarghanj. Geological Survey of Iran, Tehran

Mattei M, Muttoni G, Cifelli F (2014) A record of the Jurassic massive plate shift from the Garedu Formation of central Iran. Geology 42:555-558

Mattei M, Cifelli F, Muttoni G, Rashid H (2015) Post-Cimmerian (Jurassic-Cenozoic) palaeogeography and vertical axis tectonic rotations of Central Iran and the Alborz Mountains. J Asian Earth Sci 102:92-101

Mattei M, Cifelli F, Alimohammadian H, Rashid H (2020) The role of active strike-slip faults and opposite vertical axis rotations in accommodating Eurasia-Arabia shortening in Central Iran. Tectonophysics 774:228243

McArthur JM, Howarth RJ, Bailey TR (2001) Strontium isotope stratigraphy: LOWESS Version 3: best fit to the marine Sr-isotope curve for 0-509 Ma and accompanying look-up table for deriving numerical age. J Geol 109:155-170

McPherson JG, Shanmugan G, Moiola RJ (1987) Fan-deltas and braid deltas: varieties of coarse-grained deltas. Geol Soc of Am Bull 99:331-340

McPherson JG, Shanmugan G, Moiola RJ (1988) Fan deltas and braid deltas: conceptual problems. In: Nemec W, Steel RJ (eds) Fan deltas: Sedimentology and tectonic setting. Blackie \& Son, London, pp 14-22

Miall AD (1977) A review of the braided-river depositional environment. Earth Sci Rev 13:1-62

Miall AD (1996) The geology of fluvial deposits: sedimentary facies, basin analysis and petroleum geology. Springer, Berlin, p 582
Moussavi-Harami R, Brenner RL (1990) Lower Cretaceous (Neocomian) fluvial deposits in eastern Kopet-Dagh Basin, northeastern Iran. Cretac Res 11:163-174

Moussavi-Harami R, Mahboubi A, Nadjafi M, Brenner RL, Mortazavi $M$ (2009) Mechanism of calcrete formation in the Lower Cretaceous (Neocomian) fluvial deposits, northeastern Iran based on petrographic, geochemical data. Cretac Res 30:1146-1156

Nasrabady M, Rossetti F, Theye T, Vignaroli G (2011) Metamorphic history and geodynamic significance of the Early Cretaceous Sabzevar granulites (Sabzevar structural zone, NE Iran). Solid Earth 2:219-243

Nilsen TH, Sylvester AG (1995) Strike-slip basins. In: Busby CJ, Ingersoll RV (eds) Tectonics of sedimentary basins. Blackwell, Oxford, pp 425-457

Nur A, Ron H, Scotti O (1989) Kinematics and mechanics of tectonic block rotations. In: Cohen SC, Vanicek P (eds) Slow deformation and transmission of stress in the Earth, vol 49. Geophysical Monograph series, pp 31-46

Omrani H, Moazzen M, Oberhänsli R, Altenberger U, Lange M (2013) The Sabzevar blueschists of the North-Central Iranian micro-continent as remnants of the Neotethys-related oceanic crust subduction. Int J Earth Sci 102:1491-1512

Pirnia T, Saccani E, Torabi G, Chiari M, Goričan S, Barbero E (2020) Cretaceous tectonic evolution of the Neo-Tethys in Central Iran: evidence from petrology and age of the Nain-Ashin ophiolitic basalts. Geosci Front 11:57-81

Platt NH, Wright VP (1991) Lacustrine carbonates: facies models, facies distributions and hydrocarbon aspects. In: Anadón P, Cabrera LI, Kelts K (eds) Lacustrine facies analysis, vol 13. International Assocation of Sedimentologists Special Publication, pp 57-74

Ruttner A, Nabavi M, Hadjian J (1968) Geology of the Shirghest area (Tabas area, east Iran). Geol Surv Iran Rep 4:1-133

Ruttner A, Nabavi MH, Alavi M (1970) Geological map of the OzbakKuh Mountains 1:100,000. Geological Survey of Iran, Tehran

Saidi A, Brunet M-F, Ricou L-E (1997) Continental accretion of the Iran Block to Eurasia as seen from Late Paleozoic to Early Cretaceous subsidence curves. Geodin Acta 10:189-208

Salehi A, Tadayon M (2020) Early Cretaceous sedimentary provenance and structural evolution of the central Sanandaj-Sirjan Zone, Iran: implications for palaeogeographic reconstructions of the northern Neo-Tethyan margin. Int Geol Rev 62:1359-1386

Salehi MA, Moussavi-Harami SR, Mahboubi A, Wilmsen M, Heubeck C (2014) Tectonic and palaeogeographic implications of compositional variations within the siliciclastic Ab-Haji Formation (Lower Jurassic, east-central Iran). Neues Jahrb Geol Paläont Abh 271:21-48

Salehi MA, Moussavi-Harami SR, Mahboubi A, Fürsich FT, Wilmsen M, Heubeck C (2018) A tectono-stratigraphic record of an extensional basin: The Lower Jurassic Ab-Haji Formation of eastcentral Iran. Swiss J Geosci 111:51-78

Schairer G, Seyed-Emami K, Fürsich FT, Senowbari-Daryan B, Aghanabati SA, Majidifard MR (2000) Stratigraphy, facies analysis and ammonite fauna of the Qal'eh Dokhtar Formation at the type locality west of Boshrouyeh (east-central Iran). Neues Jahrb Geol Paläont Abh 216:35-66

Schairer G, Fürsich FT, Wilmsen M, Seyed-Emami K, Majidifard MR (2003) Stratigraphy and ammonite fauna of Upper Jurassic basinal sediments at the eastern margin of the Tabas Block (East-Central Iran). Geobios 36:195-222

Sdzuy K, Monninger W (1985) Neue Modelle des "Jakobstabes." Neues Jahrb Geol Paläont Mh 1985:300-320

Sengör AMC (1990) A new model for the late Palaeozoic-Mesozoic tectonic evolution of Iran and its implications for Oman. In: Robertson AHF, Searle MP, Ries AC (eds) The geology and tectonics 
of the Oman region, vol 49. Geological Society, London, Special Publication, pp 797-831

Sengör AMC, Altiner D, Cin A, Ustaömer T, Hsü KJ (1988) Origin and assembly of the Tethysides orogenic collage at the expense of Gondwana Land. In: Audley-Charles MG, Hallam A (eds) Gondwana and Tethys, vol 37. Geological Society, London, Special Publication, pp 119-181

Seyed-Emami K (1999) New information on the evaporitic "Ravar Formation" and the stratigraphic position of the Middle and Upper Jurassic sedimentary strata in the Ravar-Kerman area (Central Iran). Mem Fac Engineer Univ Tehran 33:81-95 [in Farsi with English abstract]

Seyed-Emami K, Fürsich FT, Wilmsen M (2004) Documentation and significance of tectonic events in the northern Tabas Block (eastcentral Iran) during the Middle and Late Jurassic. Riv Ital Paleont Stratigr 110:163-171

Seyed-Emami K, Fürsich FT, Wilmsen M (2006) New evidence on the lithostratigraphy of the Jurassic System in the northern Tabas Block, east-central Iran. Geoscience 15:75-97

Seyed-Emami K, Wilmsen M, Fürsich FT (2020) A summary of the Jurassic System in North and East-Central Iran. Zitteliana 94:99-156

Sheldon ND (2009) Red Beds. In: Gornitz V (ed) Encyclopedia of paleoclimatology and ancient environments. Springer, Dordrecht, pp 871-873

Siehl A (2015) Structural setting and evolution of the Afghan orogenic segment-a review. In: Brunet M-F, McCann T, Sobel ER (eds) Geological evolution of Central Asian basins and the western Tien Shan Range, vol 49. Geological Society, London, Special Publication, pp 57-88

Soffel H, Davoudzadeh M, Rolf C, Schmidt S (1996) New palaeomagnetic data from Central Iran and a Triassic palaeoreconstruction. Geol Runds 85:293-302

Stampfli GM, Borel GD (2002) A plate tectonic model for the Paleozoic and Mesozoic constrained by dynamic plate boundaries and restored synthetic oceanic isochrons. Earth Planet Sci Lett 196:17-33

Stöcklin J, Eftekhar-Nezhad J, Hushmand-Zadeh A (1965) Geology of the Shotori Range (Tabas area, East Iran). Geol Surv Iran Rep $3: 1-69$

Stow DAV (2005) Sedimentary rocks in the field, 2nd edn. Manson Publishing, London, p 320

Takin M (1972) Iranian geology and continental drift in the Middle East. Nature 23:147-150

Thierry J (2000) Middle Callovian (157-155 Ma). In: Dercourt J, Gaetani M, Vrielynck B, Barrier E, Biju-Duval B, Brunet MF, Cadet JP, Crasquin S, Sandulescu M (eds) Atlas Peri-Tethys palaeogeographical maps. Commission for the Geological Map of the World (CGMW/CCGM), Paris, pp 71-97

Tirrul R, Bell IR, Griffis RJ, Camp VE (1983) The Sistan suture zone of eastern Iran. Geol Soc Am Bull 94:134-150
Walker TR (1967) Formation of red beds in modern and ancient deserts. Geol Soc Am Bull 78:353-368

Walker RT, Jackson JA (2004) Active tectonics and late Cenozoic strain distribution in central and eastern Iran. Tectonics 23:TC5010

Wallace LM, Ellis S, Mann P (2008) Tectonic block rotation, arc curvature, and backarc rifting: insights into these processes in the Mediterranean and the western Pacific. IOP Conf Ser Earth Environ Sci 2:012010

Walpersdorf A, Manighetti I, Mousavi Z, Tavakoli F, Vergnolle M, Jadidi A, Hatzfeld D, Aghamohammadi A, Bigot A, Djamour Y, Nankali H, Sedighi M (2014) Present-day kinematics and fault slip rates in eastern Iran, derived from 11 years of GPS data. J Geophys Res Solid Earth 119:1359-1383

Wierzbowski H, Anczkiewicz R, Pawlak J, Rogov MA, Kuznetsov AB (2017) Revised Middle-Upper Jurassic strontium isotope stratigraphy. Chem Geol 466:239-255

Wilmsen M, Fürsich FT, Seyed-Emami K (2003) Revised lithostratigraphy of the Middle and Upper Jurassic Magu Group of the northern Tabas Block, east-central Iran. Newsl Stratigr 39:143-156

Wilmsen M, Fürsich FT, Seyed-Emami K, Majidifard MR (2009a) An overview of the lithostratigraphy and facies development of the Jurassic System on the Tabas Block, east-central Iran. In: Brunet M-F, Wilmsen M, Granath J (eds) South Caspian to Central Iran basins, vol 312. Geological Society, London, Special Publication, pp 323-344

Wilmsen M, Fürsich FT, Seyed-Emami K, Majidifard MR, Taheri J (2009b) The Cimmerian orogeny in northern Iran: tectono-stratigraphic evidence from the foreland. Terra Nova 21:211-218

Wilmsen M, Fürsich FT, Seyed-Emami K, Majidifard MR, ZamaniPedram M (2010) Facies analysis of a large-scale Jurassic shelflagoon: the Kamar-e-Mehdi Formation of east-central Iran. Facies 56:59-87

Wilmsen M, Fürsich FT, Majidifard MR (2013) The Shah Kuh Formation, a latest Barremian-early Aptian carbonate platform of Central Iran (Khur area, Yazd Block). Cretac Res 39:183-194

Wilmsen M, Fürsich FT, Majidifard J (2015) An overview of the Cretaceous stratigraphy and facies development of the Yazd Block, western Central Iran. J Asian Earth Sci 102:73-91

Wilmsen M, Berensmeier M, Fürsich FT, Schlagintweit F, Hairapetian V, Pashazadeh B, Majidifard MR (2020) Mid-Cretaceous biostratigraphy (ammonites, inoceramid bivalves and foraminifers) at the eastern margin of the Anarak Metamorphic Complex (Central Iran). Cretac Res 110:104411

Zamani-Pedram M (2011) Source, facies, and sedimentary environments of the Middle to Upper Jurassic strata in the Kerman and Tabas areas, east-central Iran. PhD thesis, Würzburg University, Würzburg, 212 p. http://opus.uni-wuerzburg.de/frontdoor/index/ index/docId/4840 